\title{
Cross-shelf gradients in phytoplankton community structure, nutrient utilization, and growth rate in the coastal Gulf of Alaska
}

\author{
Suzanne L. Strom ${ }^{1, *}$, M. Brady Olson ${ }^{1}$, Erin L. Macri ${ }^{1}$, Calvin W. Mordy ${ }^{2}$ \\ ${ }^{1}$ Shannon Point Marine Center, Western Washington University, 1900 Shannon Point Road, Anacortes, \\ Washington 98221, USA \\ ${ }^{2}$ Joint Institute for the Study of Atmosphere and Ocean, University of Washington, Seattle, Washington 98195-4235, USA
}

\begin{abstract}
The coastal Gulf of Alaska (CGOA) supports high abundances of invertebrates, fishes, and marine mammals. While variable from year to year, multi-decade fish production trends have been correlated with climate regimes such as the Pacific Decadal Oscillation. Winds, massive freshwater inputs, and complex topography in the CGOA create high-energy physical features on multiple time and space scales. This suggests that climate might be linked to higher trophic level production through the regulation of resources for primary producers. Data from spring and summer 2001 revealed seasonal and spatial variability in the factors regulating CGOA primary production. Some of the highest growth rates $\left(>1.0 \mathrm{~d}^{-1}\right.$, as estimated with the seawater dilution technique) were measured in April diatom blooms. Nitrogen limitation of growth rates was evident as early as late April and appeared to follow closely the onset of spring stratification. The summer phytoplankton community was dominated by small $(<5 \mu \mathrm{m})$ cells exhibiting varying degrees of nitrogen limitation depending on cross-shelf location. However, we observed an intense mid-summer diatom bloom in the Alaska Coastal Current, perhaps a response to a series of upwelling events. Strong cross-shelf gradients governed every aspect of phytoplankton community structure and function, including overall biomass, cell size, species composition, nutrient utilization, growth rate, and degree of macronutrient limitation. These gradients were consistent with a cross-shelf gradient in dissolved iron availability. Because the type of resource limitation and the taxonomic composition of the phytoplankton community varied across the shelf, a stepwise regression of whole-shelf phytoplankton growth rates versus resource availability had little predictive power. The effect of climate-driven resource variation on primary production in the CGOA has to be understood in the context of different community types, their production potential, and the environmental conditions that dictate their extent and stability.
\end{abstract}

KEY WORDS: Phytoplankton · Chlorophyll size class · Nitrogen · Iron · Growth regulation · Bloom • Continental shelf

Resale or republication not permitted without written consent of the publisher

\section{INTRODUCTION}

Interannual and decadal climate variations in the NE Pacific, including El Niño-La Niña cycles and the Pacific Decadal Oscillation, have been linked to variation in stocks of zooplankton, salmon, and numerous other fish species (Mysak 1986, Brodeur \& Ware 1992, Hollowed et al. 2001). The primary goal of the US
Global Ecosystem Dynamics (GLOBEC) program in the NE Pacific is to understand the mechanisms underlying these links. Variations in primary production, as driven by changes in meteorological and oceanographic conditions, could be an intermediary between climate and animals at higher trophic levels. As part of the process study component of the GLOBEC program, we sought to understand regulation of lower trophic 
level production in the northern coastal Gulf of Alaska (GCOA).

The northern Gulf of Alaska experiences strong seasonality, frequent, intense storms, and high amounts of precipitation both as snow and rain (Wilson \& Overland 1986). Large-scale gyral circulation in the NE Gulf (i.e. the recirculating arm of the eastward-flowing North Pacific current) gives rise to the Alaska current, which flows westward along and offshore the shelf break (Reed \& Schumacher 1986). Prevailing SE winds engender moderate to high downwelling rates over the shelf throughout much of the year; winds coupled with enormous freshwater runoff rates also drive the Alaska Coastal Current (ACC), a swiftly flowing, narrow (ca. $40 \mathrm{~km}$ ) 'stream' confined to the coastline and extending from the British Columbia shelf along the south coast of Alaska and ultimately into the Bering Sea (Royer 1981, Johnson et al. 1988, Stabeno et al. 1995). Glaciation acting along the coast and, during low sealevel stands, on the continental shelf, has carved a tortuous coastline (Fig. 1) with which the ACC interacts.

Despite the downwelling nature of the CGOA, the region supports high abundances of invertebrates, fishes and marine mammals (Calkins 1986, OCSEAP 1986). This indicates a high regional productivity, although information on phytoplankton biomass and primary production in the CGOA is severely limited (Sambrotto \& Lorenzen 1986). A high-productivity downwelling system poses a seeming paradox. Important physical considerations, which strongly influence the phytoplankton community, are that downwelling dominates in winter, advecting macronutrient-rich, iron-poor basin water onto the shelf, but that other crossshelf exchange mechanisms (e.g. Ladd et al. 2005) dominate in summer, when downwelling is typically weak to non-existent (Fig. 2).

The CGOA experiences intense seasonality in oceanographic conditions. A spring bloom in April or May is triggered by increased irradiance due to a shoaling mixed layer, longer daylength, decreased cloud cover, or some combination of these influences (Napp et al. 1996). Salinity stratification (primarily on the inner shelf) followed by shelf-wide temperature stratification gives rise to a strongly 2-layered summer ecosystem with a subsurface chlorophyll maximum (SCM) on the pycnocline at 15 to $25 \mathrm{~m}$. Nutrient replenishment occurs during fall and winter and is ultimately fueled by the movement of offshore waters onto the deep shelf during the previous spring and summer.
In the context of longer-term meteorological and oceanographic patterns during our study, 2001 was near the end of a relatively brief (4 yr) cool period. The Pacific Decadal Oscillation (PDO) index, a measure of the strength of the climate anomaly, was moderately negative during 2001 (Peterson \& Schwing 2003). Freshwater discharge into the CGOA was relatively low during the winter preceding our study, while downwelling wind stress was substantial ( $\mathrm{T}$. Royer pers. comm.). There were no major shelf break eddies in the study region during 2001 (C. Ladd pers. comm.). Thus conditions during our study were probably representative of typical cool period (negative PDO) conditions, with limited shelf-break eddy activity.

Establishing the nature of resource limitation of phytoplankton growth is essential for understanding how climate variation might impact primary (and hence secondary) production in the CGOA. For example, Gargett (1997) has hypothesized that phytoplankton in this region is primarily light-limited, so that climate regimes favoring decreased wind mixing and increased stratification should enhance primary production levels. Since reduced mixing decreases the availability of nutrients from deep water, any tendency toward nutrient limitation in this ecosystem will work in opposition to this hypothesized climate-production relationship. Stratification and nutrient limitation have long been known to limit late spring and summer productivity in the Strait of Georgia (southern British Columbia coast; Harrison et al. 1983). More recently,
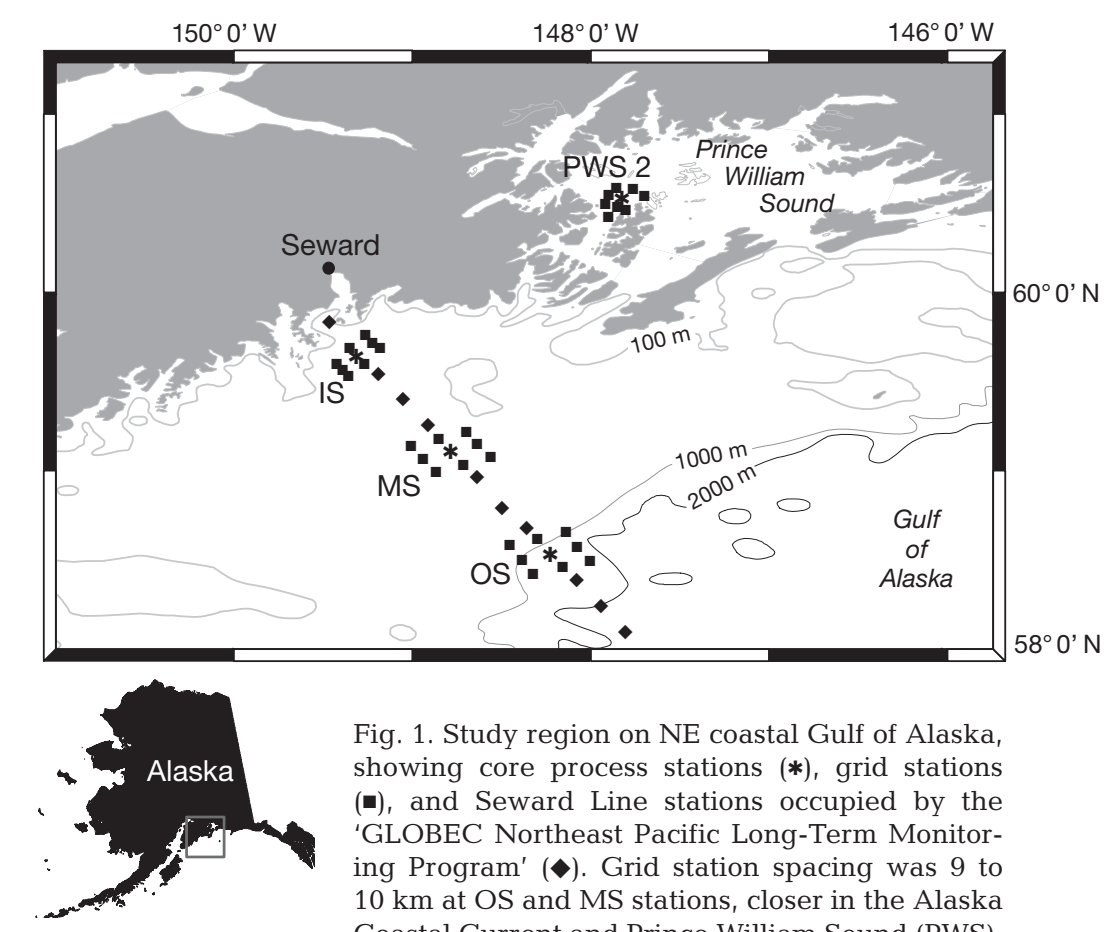

Fig. 1. Study region on NE coastal Gulf of Alaska, showing core process stations $(*)$, grid stations (घ), and Seward Line stations occupied by the 'GLOBEC Northeast Pacific Long-Term Monitoring Program' ( $\bullet$ ). Grid station spacing was 9 to $10 \mathrm{~km}$ at $\mathrm{OS}$ and MS stations, closer in the Alaska Coastal Current and Prince William Sound (PWS); IS: inner shelf; MS: mid shelf; OS: outer shelf 


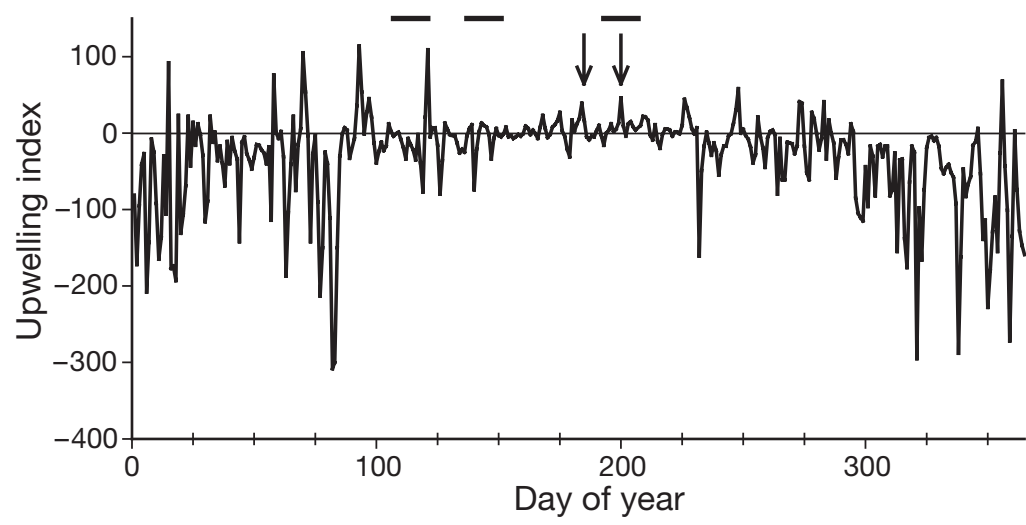

Fig. 2. Bakun upwelling index $\left(\mathrm{m}^{3} \mathrm{~s}^{-1}[100 \mathrm{~m} \text { coastline }]^{-1}\right)$ for 2001 at $60^{\circ} \mathrm{N}$, $149^{\circ} \mathrm{W}$ near inner Seward Line in coastal Gulf of Alaska. Arrows indicate upwelling events peaking on 3 and 19 July (2001). Horizontal bars at top show cruise periods. (Data from NOAA Pacific Fisheries Environmental Laboratories)

Childers et al. (2005) and Whitney et al. (2005) described summer macronutrient depletion in NE Pacific coastal waters stretching from Oregon to our study region in Alaska. One of our goals in the GLOBEC program was to determine phytoplankton growth rates and the degree to which they were nutrient-limited during spring and summer. In this way we can address the potential for meteorological and oceanographic events to stimulate phytoplankton production through nutrient enrichment.

In this paper we describe the cross-shelf distribution of phytoplankton community structure and nutrient regulation of growth rates during spring and summer 2001; a further study (Strom et al. in press) examines microzooplankton grazing and community composition during the same study period. We found evidence for nitrogen limitation of phytoplankton growth during both spring and summer. Strong cross-shelf gradients consistent with a gradient in dissolved iron availability were seen in every aspect of phytoplankton community structure, as well as in growth rate and degree of macronutrient limitation. This spatial gradient modulated the response of the phytoplankton to seasonal changes in the environment, and probably influenced the phytoplankton community response to physical events.

\section{MATERIALS AND METHODS}

Station locations and hydrography. The data presented here were collected in 2001 during three $15 \mathrm{~d}$ cruises aboard the RV 'Alpha Helix': 17 April to 1 May, 17 to 31 May, and 12 to 26 July. Water for incubation experiments was collected from 4 'core stations' chosen to encompass a range of coastal environments, from
Prince William Sound (PWS) in the north through a cross-shelf gradient in the south (Fig. 1). While all shelf stations were positioned along the Seward Line, a cross-shelf transect that is monitored by the GLOBEC NE Pacific Long-Term Observation Program, core station locations varied slightly among and within cruises (Table 1). The inner shelf (IS) station was positioned in the core of the Alaska Coastal Current (ACC), as indicated by hydrographic surveys conducted daily while in the ACC region. The mid shelf (MS) station was chosen to encompass significant hydrographic or biological features as identified from surveys or from SeaWiFS ocean surface color satellite images. PWS and outer shelf (OS) stations were always in the same location, the former in a deep basin at the north end of Knight Island Passage, and the latter just seaward of the shelf break in water of $1500 \mathrm{~m}$ depth. Water column measurements were made at both the 4 core stations (OS, MS, IS, PWS) and a set of 8 'grid stations' encompassing each core (Fig. 1).

Hydrographic measurements (temperature, salinity) were made with a Seabird SBE 9/11 Plus CTD system. The instrument package also contained a Li-Cor spherical sensor for photosynthetically active radiation and a Seatech FL0500 submersible fluorometer for detection of in vivo chlorophyll a fluorescence. Incident (sea surface) irradiance was logged by a Li-Cor $2 \pi$ sensor mounted on the ship's superstructure. Water samples for measurement of properties (nutrients, chlorophyll, phyto- and microzooplankton community composition) and for incubation experiments were collected using either 5 or $10 \mathrm{l}$ Niskin bottles with external spring closures, mounted on the CTD rosette.

Nutrient and chlorophyll analysis. Samples for analysis of macronutrients (nitrate, nitrite, phosphate, silicic acid) were drawn from Niskin bottles into $50 \mathrm{ml}$ syringes and filtered $(0.45 \mu \mathrm{m}$ cellulose acetate membranes) into $30 \mathrm{ml}$ acid-washed high-density polyethelene bottles after 3 rinses. Filtered samples were frozen upright at $-20^{\circ} \mathrm{C}$, taking care to leave appropriate head space (Dore et al. 1996), and transported on dry ice to a shore-based laboratory for analysis. The majority of samples were analyzed within $8 \mathrm{mo}$, but some samples were analyzed 11 mo after collection. Samples were thawed in a cool water bath, dried, and immediately analyzed. Phosphate concentrations were determined using a Technicon AutoAnalyzer II; silicic acid, nitrate and nitrite concentrations were determined using components from Alpkem and Perstorp instrumentation. Analytical methods were from Armstrong et al. (1967) and Atlas et al. (1971); we closely followed the WOCE- 
Table 1. Initial conditions for dilution experiments in Gulf of Alaska (GAK) during 2001. Water was collected from depth corresponding to $50 \%$ surface irradiance except where otherwise noted. When not from initial experimental water sample, nutrient data are from CTD cast closest in time at that station (but always on same day as corresponding experiment). OS: outer shelf; MS: mid shelf; IS: inner shelf; PWS: Prince William Sound. I: total incident irradiance (as photosynthetically active radiation) received during incubation period. $T$ : surface temperature at seawater collection site (representative of temperature during $24 \mathrm{~h}$ incubations); Sal: salinity at seawater collection depth; nd: not determined

\begin{tabular}{|c|c|c|c|c|c|c|c|c|c|c|c|c|}
\hline \multirow{2}{*}{ Date } & \multirow{2}{*}{$\begin{array}{c}\text { Expt } \\
\text { no. }\end{array}$} & \multirow[b]{2}{*}{ Region } & \multirow{2}{*}{$\overline{S t n}_{\text {Lo }}$} & \multirow{2}{*}{$\begin{array}{l}\text { ocation } \\
{ }^{\circ} \mathrm{N} \text { Lat }\end{array}$} & \multirow[b]{2}{*}{${ }^{\circ} \mathrm{W}$ Long } & \multirow{2}{*}{$\begin{array}{l}\text { Depth } \\
\text { (m) }\end{array}$} & \multirow{2}{*}{$\begin{array}{c}I \\
\left(\mathrm{~mol} \mathrm{~m}^{-2}\right)\end{array}$} & \multirow{2}{*}{$\begin{array}{c}T \\
\left({ }^{\circ} \mathrm{C}\right)\end{array}$} & \multirow{2}{*}{$\begin{array}{c}\text { Sal } \\
(\mathrm{ppt})\end{array}$} & \multicolumn{3}{|c|}{ Nutrients $(\mu \mathrm{M})-$} \\
\hline & & & & & & & & & & $\mathrm{PO}_{4}{ }^{3-}$ & $\mathrm{SiO}_{4}{ }^{2-}$ & $\mathrm{NO}_{3}^{-}$ \\
\hline \multicolumn{13}{|l|}{ April } \\
\hline 17 & 1 & OS & GAK-10 & 58.54 & 148.21 & 10 & nd & 5.8 & 32.6 & nd & nd & nd \\
\hline 18 & 2 & OS & GAK-10 & 58.54 & 148.21 & 10 & 32.5 & 5.9 & 32.6 & 1.33 & 21.7 & 14.2 \\
\hline 19 & 3 & OS & GAK-10 & 58.54 & 148.21 & 10 & 30.0 & 6.0 & 32.5 & 1.29 & 21.5 & 14.0 \\
\hline 20 & 4 & MS & GAK-6 & 59.12 & 148.77 & 7 & 26.9 & 5.8 & 32.1 & 1.36 & 26.0 & 15.5 \\
\hline 21 & 5 & MS & GAK-6 & 59.12 & 148.77 & 10 & 16.3 & 5.8 & 32.1 & 1.31 & 24.3 & 14.7 \\
\hline 22 & 6 & IS & ACC-2 & 59.66 & 149.29 & 4 & 32.4 & 5.3 & 31.3 & 0.48 & 2.6 & 3.0 \\
\hline 23 & 7 & IS & ACC-2 & 59.66 & 149.29 & 3 & 19.1 & 5.2 & 31.0 & 0.48 & 2.6 & 3.0 \\
\hline 24 & 8 & IS & ACC-2 & 59.66 & 149.29 & 5 & 15.9 & 5.8 & 31.8 & 1.22 & 24.0 & 13.5 \\
\hline 25 & 9 & IS & ACC-2 & 59.66 & 149.29 & 5 & 14.0 & 5.6 & 31.8 & nd & nd & nd \\
\hline 26 & 10 & PWS & PWS-2 & 60.53 & 147.80 & 3 & 21.2 & 5.8 & 30.7 & 0.39 & 1.7 & 2.1 \\
\hline 27 & 11 & PWS & PWS-2 & 60.53 & 147.80 & 3 & 15.5 & 5.9 & 30.6 & 0.33 & 1.6 & 1.8 \\
\hline 28 & $12^{\mathrm{a}}$ & PWS & PWS-2 & 60.53 & 147.80 & 12 & 51.2 & 5.5 & 31.1 & nd & nd & nd \\
\hline 29 & 13 & PWS & PWS-2 & 60.53 & 147.80 & 3 & 40.1 & 5.5 & 30.2 & nd & nd & nd \\
\hline \multicolumn{13}{|l|}{ May } \\
\hline $17^{\prime}$ & 1 & OS & GAK-10 & 58.54 & 148.21 & 6.5 & 54.9 & 7.0 & 32.5 & nd & nd & nd \\
\hline 18 & 2 & OS & GAK-10 & 58.54 & 148.21 & 6.5 & 51.1 & 6.8 & 32.5 & 1.48 & 24.0 & 16.8 \\
\hline 19 & 3 & OS & GAK-10 & 58.54 & 148.21 & 7 & 20.7 & 7.0 & 32.5 & 1.11 & 21.3 & 10.8 \\
\hline 21 & 5 & PWS & PWS-2 & 60.53 & 147.80 & 4.5 & 23.5 & 7.6 & 30.2 & 0.17 & 0.0 & 0.1 \\
\hline 22 & 6 & PWS & PWS-2 & 60.53 & 147.80 & 4.5 & 43.3 & 7.1 & 30.4 & 0.46 & 1.2 & 1.9 \\
\hline 23 & 7 & PWS & PWS-2 & 60.53 & 147.80 & 5 & 43.6 & 8.0 & 29.9 & 0.36 & 0.4 & 0.8 \\
\hline 24 & 8 & MS & GAK-4 & 59.41 & 149.05 & 7 & 41.3 & 8.0 & 32.3 & 1.08 & 21.4 & 9.9 \\
\hline 25 & 9 & MS & $4 \mathrm{iW}$ & 59.26 & 149.28 & 5 & 44.4 & 7.5 & 32.3 & 0.77 & 9.9 & 5.1 \\
\hline 26 & 10 & MS & GAK-4 & 59.41 & 149.05 & 6.5 & 45.0 & 8.3 & 32.3 & 1.01 & 21.4 & 9.6 \\
\hline 27 & 11 & MS & EXP11 & 59.14 & 149.21 & 3 & 43.1 & 7.9 & 32.3 & 0.24 & 0.7 & 0.4 \\
\hline 28 & 12 & IS & $\mathrm{ACC}-1$ & 59.73 & 149.36 & 3 & 34.8 & 8.3 & 31.5 & 0.23 & 3.1 & 0.2 \\
\hline 29 & 13 & IS & ACC-1 & 59.73 & 149.36 & 2.5 & 42.6 & 8.6 & 31.7 & 0.14 & 0.4 & 0.3 \\
\hline 30 & 14 & IS & ACC-1 & 59.73 & 149.36 & 3 & 53.4 & 9.1 & 30.7 & 0.47 & 3.3 & 2.3 \\
\hline \multicolumn{13}{|l|}{ July } \\
\hline 12 & 1 & IS & ACC-1 & 59.73 & 149.36 & 4 & 24.1 & 11.5 & 31.0 & 0.12 & 1.0 & 0.1 \\
\hline 13 & 2 & IS & ACC-1 & 59.73 & 149.36 & 4 & 28.9 & 12.1 & 31.5 & 0.26 & 4.6 & 0.1 \\
\hline 14 & $3^{a}$ & IS & ACC-1 & 59.73 & 149.36 & 17 & 28.6 & 12.2 & 31.0 & 0.67 & 6.1 & 2.9 \\
\hline 15 & 4 & MS & GAK-6 & 59.12 & 148.77 & 5 & 22.8 & 12.4 & 32.0 & 0.36 & 9.3 & 0.1 \\
\hline 16 & 5 & MS & GAK-6 & 59.12 & 148.77 & 5 & 35.6 & 12.6 & 31.9 & 0.36 & 9.3 & 0.1 \\
\hline 17 & $6^{\mathrm{a}}$ & MS & GAK-6 & 59.12 & 148.77 & 19 & 42.5 & 12.1 & 32.2 & 0.67 & 12.9 & 3.9 \\
\hline 18 & 7 & OS & GAK-10 & 58.54 & 148.21 & 5 & 20.7 & 14.0 & 32.2 & 0.56 & 16.9 & 3.0 \\
\hline 19 & 8 & OS & GAK-10 & 58.54 & 148.21 & 5 & 19.5 & 13.6 & 32.3 & 0.43 & 7.0 & 0.2 \\
\hline 20 & $9^{a}$ & OS & GAK-10 & 58.54 & 148.21 & 25 & 13.7 & 13.4 & 32.2 & 1.21 & 18.8 & 11.8 \\
\hline 22 & 10 & PWS & PWS-2 & 60.53 & 147.80 & 5.5 & 8.8 & 13.7 & 26.3 & 0.09 & 0.3 & 0.1 \\
\hline 23 & $11^{\mathrm{a}}$ & PWS & PWS-2 & 60.53 & 147.80 & 18 & 20.3 & 13.3 & 29.3 & 0.57 & 6.4 & 3.8 \\
\hline 24 & 12 & PWS & PWS-2 & 60.53 & 147.80 & 5 & 22.6 & 13.7 & 26.6 & 0.14 & 0.5 & 0.4 \\
\hline 25 & 13 & IS & ACC-1 & 59.73 & 149.36 & 3 & 25.7 & 11.8 & 28.9 & 0.15 & 0.2 & 0.2 \\
\hline
\end{tabular}

JGOFS standardization and analysis procedures specified by Gordon et al. (1993) including calibration of glass- and plasticware, preparation of primary and secondary standards, and corrections for blanks and refractive index. Due to the potential for polymerization of silicic acid in frozen samples (Macdonald et al. 1986), a second analysis was performed after refrigeration for several days. Replicate silicic acid measurements were, on average, within $0.3 \mu \mathrm{M}$, and this result was consistent with the laboratory results of Macdonald et al. (1986), i.e. with the low silicic acid:salinity ratios observed on the Alaskan shelf and sufficient thawing, no loss of reactive silicic acid was observed. Overall, analytical precision of nutrient measurements was ca. $4 \%$, and limits of detection were $0.1 \mu \mathrm{M}$ (nitrate and silicic acid) and $0.01 \mu \mathrm{M}$ (phosphate). 
We observed a range of nutrient concentrations in each sampling region during each cruise. This localized variability was assumed to result from the utilization of nutrients by phytoplankton prior to and during our occupation of the site, since winter nutrient levels across the shelf are nearly homogeneous (Childers et al. 2005). We used the slopes of the nitrate-phosphate and silicic acid-nitrate relationships for each region and month as a proxy for phytoplankton nutrient utilization at that site and time. Utilization ratios were calculated only for months and regions showing a $>2 \mu \mathrm{M}$ range in nitrate or silicic acid concentration, since changes of $<2 \mu \mathrm{M}$ were associated with clusters of data points rather than linear relationships. For silicic acid:nitrate utilization, we report ratios only for diatom-dominated regions and months. Only when diatoms constitute the majority of the phytoplankton biomass can bulk nitrate uptake be physiologically associated with silicic acid uptake. When non-diatom phytoplankton predominate, the fraction of total nitrate uptake associated with silicic acid uptake is unknown, and physiologically meaningful uptake ratios cannot be calculated. In addition, samples with nitrate concentrations $<0.5 \mu \mathrm{M}$ (primarily from July) were excluded from all N:P slope calculations. Below $0.5 \mu \mathrm{M}$, phosphate use was not associated with measurable changes in nitrate, indicating that phytoplankton production was fueled entirely by regenerated $\mathrm{N}$ at these times.

Water column and experiment chlorophyll samples were size-fractionated using a 'fractionation cascade'. Water passed through a sequential arrangement of 3 filters: $20 \mu \mathrm{m}$ pore-size polycarbonate $(47 \mathrm{~mm}), 5 \mu \mathrm{m}$ pore-size polycarbonate $(47 \mathrm{~mm})$ and $0.7 \mu \mathrm{m}$ effective pore-size glass fiber $(25 \mathrm{~mm})$. Preliminary tests showed that $47 \mathrm{~mm}$ glass fiber filters had a reduced chlorophyll extraction efficiency compared with filters $25 \mathrm{~mm}$ in diameter. Filters were immediately placed in $90 \%$ acetone, extracted for $24 \mathrm{~h}\left(-20^{\circ} \mathrm{C}\right.$, darkness), and analyzed for chlorophyll and phaeopigments a on a Turner TD700 (April, May) or Turner 112 (July) fluorometer. Total chlorophyll concentrations were estimated from the sum of the 3 size fractions.

Phytoplankton growth rate and nutrient limitation assays. Phytoplankton growth rates were measured using the seawater dilution technique (Landry \& Hassett 1982). This method yields both net growth rates (cellular growth minus losses due to density-dependent agents of mortality in the incubation bottles, primarily microzooplankton grazing) and intrinsic growth rates (rates of cellular growth in the absence of such losses). Filtered seawater, typically collected from the depth corresponding to $50 \%$ surface irradiance $\left(50 \% I_{0}\right)$ but occasionally from the sub-surface chlorophyll maximum (SCM; Table 1), was prepared by pool- ing contents of multiple Niskin bottles into a polycarbonate carboy and gravity-filtering the carboy contents through a Pall Gelman pleated capsule filter with $0.2 \mu \mathrm{m}$ Versapor membrane. Cartridge filters were pre-cleaned by soaking in $10 \% \mathrm{HCl}$ overnight. All polycarbonate containers were cleaned with $10 \%$ $\mathrm{HCl}$ and rinsed with deionized water (Milli-Q grade) and seawater; all seawater transfers were done with $\mathrm{HCl}$-cleaned silicone tubing. Incubation bottles (2.35 l polycarbonate) were filled with measured volumes of filtered seawater to achieve dilution levels of 9, 16, 24, 41 , and $61 \%$ whole seawater (each in duplicate). An additional pair of bottles diluted to $4 \%$ was added during the May and July cruises.

Unfiltered (whole) seawater was collected similarly, and nearly always from a later (ca. $45 \mathrm{~min}$ ) CTD cast. This seawater was gently transferred through $200 \mu \mathrm{m}$ mesh-size Nitex to exclude macrozooplankton and pooled in a polycarbonate carboy. Whole seawater (wsw) was siphoned from this carboy into the measured volumes of filtered seawater in incubation bottles to fill them completely; wsw was gently stirred with a glass/plastic plunger to keep large cells (e.g. chain diatoms) in suspension while siphoning. An additional set of incubation bottles (2 in April, 4 in May and July) was filled completely with wsw. Initial samples (sizefractionated chlorophyll, phyto- and microzooplankton community composition) were taken at intervals during the filling process by siphoning from the wsw carboy. Initial chlorophyll levels in diluted bottles were calculated from wsw chlorophyll concentrations (Table 2) and theoretical dilution levels. During the May and July cruises, macronutrients were added to the dilution series to assess the degree of nutrient limitation of phytoplankton growth, as well as to meet the assumptions of the dilution method under potentially nutrientlimiting conditions (Landry 1993). All diluted bottles and two $100 \%$ wsw bottles were enriched with nitrate $\left(\mathrm{NaNO}_{3}\right)$ and phosphate $\left(\mathrm{Na}_{2} \mathrm{HPO}_{4}\right)$. The remaining 2 unenriched $100 \%$ wsw bottles served as controls for the effects of nutrient addition on growth. Duplicate initial nutrient samples were taken from the wsw carboy and an additional (not incubated) nutrient-spiked bottle during five July experiments. These showed that actual enrichments averaged $4.7 \mu \mathrm{M}$ for nitrate and $0.27 \mu \mathrm{M}$ for phosphate.

Two types of preserved samples were taken (each in duplicate) from the wsw carboy during the experiment set-up, one preserved with acid Lugol's solution for inverted light microscopy (final concentration 10\%), the other with glutaraldehyde (final concentration $0.5 \%$ ) for epifluorescence microscopy. Sample processing and analysis details, including biomass and composition of the microzooplankton community, are presented elsewhere (Strom et al. in press). We used in- 
verted microscopy to identify and assess the condition of diatoms, and epifluorescence microscopy to evaluate the taxonomic composition of the $<20 \mu \mathrm{m}$ phytoplankton.

Dilution series bottles were incubated for $24 \mathrm{~h}$ in seawater-cooled, Plexiglas deck incubators. Neutral density screening was used to screen bottles to light levels corresponding to water collection depths. Most incubations began mid to late morning, but some began in the late afternoon and the first experiment of each

Table 2. Initial chlorophyll concentrations $\left(\mu \mathrm{g} \mathrm{l}^{-1}\right)$ for dilution experiments in coastal Gulf of Alaska during 2001. Integrated (Int) (0 to $50 \mathrm{~m}$ ) upper water column chlorophyll $\left(\mathrm{mg} \mathrm{m}^{-2}\right)$ also shown for vertical profile sampled closest in time to each dilution experiment. Abbreviations as in Table 1

\begin{tabular}{|c|c|c|c|c|c|c|c|}
\hline \multirow[t]{2}{*}{ Date } & \multirow{2}{*}{$\begin{array}{c}\text { Expt } \\
\text { no. }\end{array}$} & \multirow[t]{2}{*}{ Stn } & \multirow[b]{2}{*}{$>20 \mu \mathrm{m}$} & \multicolumn{2}{|c|}{ Chlorophyll } & \multirow[b]{2}{*}{ Total } & \multirow[b]{2}{*}{ Int } \\
\hline & & & & $5-20 \mu \mathrm{m}$ & $<5 \mu \mathrm{m}$ & & \\
\hline \multicolumn{8}{|l|}{ April } \\
\hline 17 & 1 & GAK-10 & 0.06 & 0.08 & 0.22 & 0.35 & 20.4 \\
\hline 18 & 2 & GAK-10 & 0.04 & 0.07 & 0.19 & 0.30 & 16.4 \\
\hline 19 & 3 & GAK-10 & 0.05 & 0.06 & 0.17 & 0.28 & 11.5 \\
\hline 20 & 4 & GAK-6 & 0.03 & 0.07 & 0.26 & 0.35 & 16.4 \\
\hline 21 & 5 & GAK-6 & 0.05 & 0.03 & 0.27 & 0.34 & 14.7 \\
\hline 22 & 6 & ACC-2 & 5.31 & 0.17 & 0.14 & 5.59 & 237.4 \\
\hline 23 & 7 & $\mathrm{ACC}-2$ & 4.85 & 0.28 & 0.14 & 5.27 & 302.3 \\
\hline 24 & 8 & ACC-2 & 3.21 & 0.29 & 0.24 & 3.74 & 58.6 \\
\hline 25 & 9 & ACC-2 & 3.17 & 0.27 & 0.30 & 3.74 & 57.0 \\
\hline 26 & 10 & PWS-2 & 1.57 & 0.16 & 0.09 & 1.83 & 80.8 \\
\hline 27 & 11 & PWS-2 & 0.51 & 0.14 & 0.13 & 0.80 & 44.6 \\
\hline 28 & $12^{\mathrm{a}}$ & PWS-2 & 1.00 & 0.19 & 0.08 & 1.27 & 79.8 \\
\hline 29 & 13 & PWS-2 & 0.64 & 0.14 & 0.14 & 0.92 & 61.9 \\
\hline \multicolumn{8}{|l|}{ May } \\
\hline 17 & 1 & GAK-10 & 0.02 & 0.15 & 0.75 & 0.92 & 31.1 \\
\hline 18 & 2 & GAK-10 & 0.05 & 0.13 & 0.57 & 0.75 & 31.7 \\
\hline 19 & 3 & GAK-10 & 0.06 & 0.13 & 0.74 & 0.94 & 24.7 \\
\hline 21 & 5 & PWS-2 & 0.35 & 0.15 & 0.19 & 0.69 & 50.6 \\
\hline 22 & 6 & PWS-2 & 0.69 & 0.25 & 0.19 & 1.13 & 83.0 \\
\hline 23 & 7 & PWS-2 & 0.19 & 0.10 & 0.15 & 0.45 & 38.9 \\
\hline 24 & 8 & GAK-4 & 0.05 & 0.05 & 0.31 & 0.41 & 15.7 \\
\hline 25 & 9 & $4 \mathrm{iW}$ & 1.87 & 0.13 & 0.34 & 2.34 & 75.5 \\
\hline 26 & 10 & GAK-4 & 0.07 & 0.07 & 0.38 & 0.52 & 27.7 \\
\hline 27 & 11 & EXP11 & 2.45 & 0.12 & 0.14 & 2.71 & 81.7 \\
\hline 28 & 12 & ACC-1 & 2.05 & 0.14 & 0.19 & 2.38 & 93.6 \\
\hline 29 & 13 & ACC-1 & 3.16 & 0.15 & 0.23 & 3.54 & 65.1 \\
\hline 30 & 14 & ACC-1 & 0.92 & 0.13 & 0.19 & 1.25 & 26.3 \\
\hline \multicolumn{8}{|l|}{ July } \\
\hline 12 & 1 & ACC-1 & 1.10 & 0.18 & 0.19 & 1.48 & 88.3 \\
\hline 13 & 2 & ACC-1 & 1.10 & 0.38 & 0.50 & 1.98 & 140.0 \\
\hline 14 & $3^{\mathrm{a}}$ & ACC-1 & 0.97 & 0.21 & 0.08 & 1.26 & 75.7 \\
\hline 15 & 4 & GAK-6 & 0.05 & 0.17 & 0.84 & 1.07 & 39.2 \\
\hline 16 & 5 & GAK-6 & 0.07 & 0.19 & 0.74 & 1.00 & 51.5 \\
\hline 17 & $6^{\mathrm{a}}$ & GAK-6 & 0.07 & 0.19 & 0.70 & 0.96 & 49.8 \\
\hline 18 & 7 & GAK-10 & 0.07 & 0.25 & 0.66 & 0.98 & 31.3 \\
\hline 19 & 8 & GAK-10 & 0.04 & 0.11 & 0.35 & 0.50 & 18.6 \\
\hline 20 & $9^{a}$ & GAK-10 & 0.13 & 0.29 & 0.91 & 1.33 & 22.3 \\
\hline 22 & 10 & PWS-2 & 0.41 & 0.14 & 0.26 & 0.81 & 33.2 \\
\hline 23 & $11^{\mathrm{a}}$ & PWS-2 & 0.31 & 0.14 & 0.18 & 0.63 & 31.8 \\
\hline 24 & 12 & PWS-2 & 0.29 & 0.07 & 0.13 & 0.49 & 28.6 \\
\hline 25 & 13 & ACC-1 & 3.63 & 0.19 & 0.20 & 4.03 & 184.2 \\
\hline
\end{tabular}

cruise began in the late evening. After incubation, final samples were taken for size-fractionated chlorophyll (all bottles, each sampled in duplicate), microscopy and, occasionally, macronutrients (100\% wsw bottles only, each sampled singly).

Net growth rates $\left(k, \mathrm{~d}^{-1}\right)$ for the 3 chlorophyll size fractions, as well as for total chlorophyll, were calculated as $(1 / t)(\ln [\mathrm{Pt} / \mathrm{P} 0])$, where $\mathrm{Pt}$ is the final chlorophyll concentration, P0 is the initial chlorophyll concentration, and $t$ is the incubation time (nearly always $1.0 \mathrm{~d})$. Intrinsic growth rates $\left(\mu, \mathrm{d}^{-1}\right)$ of phytoplankton were estimated from the $y$-intercept of net growth rates regressed on Fraction wsw. For experiments exhibiting saturated grazing (i.e. a leveling of net growth rate across the least-dilute bottles) (Gallegos 1989), instrinsic growth estimates were based on regression of net growth rates in only the most dilute bottles (generally those with $\leq 40 \%$ wsw). For May and July experiments, intrinsic growth rates estimated from the dilution series are nutrient-enriched rates $\left(\mu_{n}\right)$. To evaluate the effect of added nutrients on intrinsic growth rates of phytoplankton, we calculated unenriched growth rates $\left(\mu_{0}\right)$ from $\mu_{0}=k_{0}+g$, where $k_{0}$ is the net growth rate of phytoplankton in unenriched, 100\% wsw bottles and $\mathrm{g}$ is the microzooplankton grazing rate; $g$, in turn, was estimated as the slope of the regression for experiments with linear relationships between net growth and fraction wsw, and as $\mathrm{g}=\mu_{\mathrm{n}}-k_{\mathrm{n}}$ (where $k_{\mathrm{n}}$ is the net growth rate of phytoplankton in enriched, $100 \%$ wsw bottles) for experiments with saturated grazing. Significant differences between growth rates in unenriched versus nutrient-enriched bottles were determined by computing $95 \%$ confidence intervals for the 2 types of rates and determining whether or not they overlapped. For unenriched growth, $95 \%$ confidence intervals were derived from duplicate rate estimates from the undiluted bottles. For enriched growth, 95\% confidence intervals were determined from the regression statistics. Net growth rates in the most highly diluted bottles were generally equivalent to intrinsic growth rates estimated through the regression 
Table 3. Relationships between net growth rates in highly dilute treatments $(9 \%$ whole seawater, April $; 4 \%$ whole seawater, May and July) and intrinsic growth rates estimated using regression method (see 'Materials and methods'). Tabulated values are slopes of relationships (boldface), followed by $y$-intercepts and (in parentheses) Pearson product moment correlation coefficients

\begin{tabular}{|lccc|}
\hline $\begin{array}{l}\text { Chlorophyll } \\
\text { size fraction }\end{array}$ & April & May & July \\
\hline$>20 \mu \mathrm{m}$ & $\mathbf{0 . 9 7}$ & $\mathbf{1 . 0 2}$ & \\
& 0.02 & 0.01 & $\mathbf{0 . 9 4}$ \\
& $(0.976)$ & $(0.936)$ & $(0.944)$ \\
$5-20 \mu \mathrm{m}$ & $\mathbf{0 . 9 0}$ & $\mathbf{0 . 9 3}$ & $\mathbf{0 . 9 1}$ \\
& 0.08 & 0.04 & 0.07 \\
& $(0.794)$ & $(0.835)$ & $(0.928)$ \\
$<5 \mu \mathrm{m}$ & $\mathbf{0 . 9 4}$ & $\mathbf{1 . 0 1}$ & $\mathbf{0 . 9 6}$ \\
& -0.01 & 0.04 & 0.06 \\
Total & $(0.784)$ & $(0.914)$ & $(0.976)$ \\
& $\mathbf{1 . 0 3}$ & $\mathbf{0 . 9 2}$ & $\mathbf{0 . 9 2}$ \\
& -0.01 & 0.10 & 0.09 \\
& $(0.924)$ & $(0.941)$ & $(0.987)$ \\
\hline
\end{tabular}

method for all chlorophyll size fractions and cruises (Table 3), as predicted if a high level of dilution effectively eliminates encounters between microzooplankton grazers and phytoplankton prey.

\section{RESULTS}

\section{Chlorophyll biomass and size composition}

During our 2001 cruises, the highest integrated chlorophyll biomass and the greatest variability were consistently found in the ACC waters of the inner shelf (Fig. 3A). High chlorophyll levels (>50 $\mathrm{mg} \mathrm{m}^{-2}$ ) were also found on the mid shelf in May, particularly in waters slightly west of the Seward Line, and in PWS in spring. System-wide, chlorophyll concentrations $>2 \mu \mathrm{g} \mathrm{l}^{-1}$ were associated with a high proportion of large $(>20 \mu \mathrm{m})$ cells, primarily chain diatoms (Fig. 4). However, the moderate summer chlorophyll levels on the mid and outer shelf consisted mainly of small $(<5 \mu \mathrm{m})$ phytoplankton cells (Figs. 3B \& 4).

Summer stratification of the water column on the shelf was accompanied by a change in the vertical distribution of the phytoplankton, with maximum chlorophyll concentrations distributed throughout the mixed layer in spring and associated with the pycnocline in summer (Fig. 5). Regardless of sampling site or time, the size composition of the phytoplankton community was nearly constant with depth (data not shown).
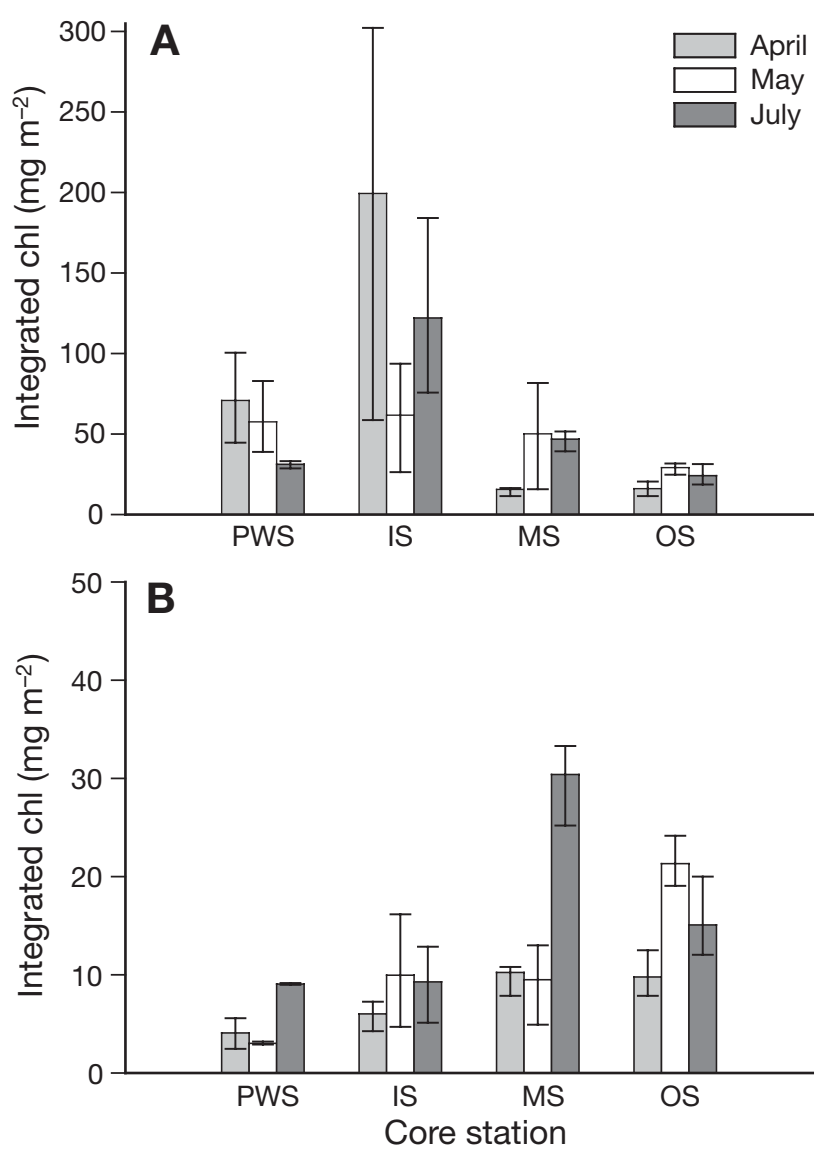

Fig. 3. Average and range of integrated (0 to $50 \mathrm{~m})$ total chlorophyll (A) and chlorophyll <5 $\mu$ m (B) from core station vertical profiles taken during April, May and July 2001. Note different scales of $y$-axes. Site abbreviations as for Fig. 1

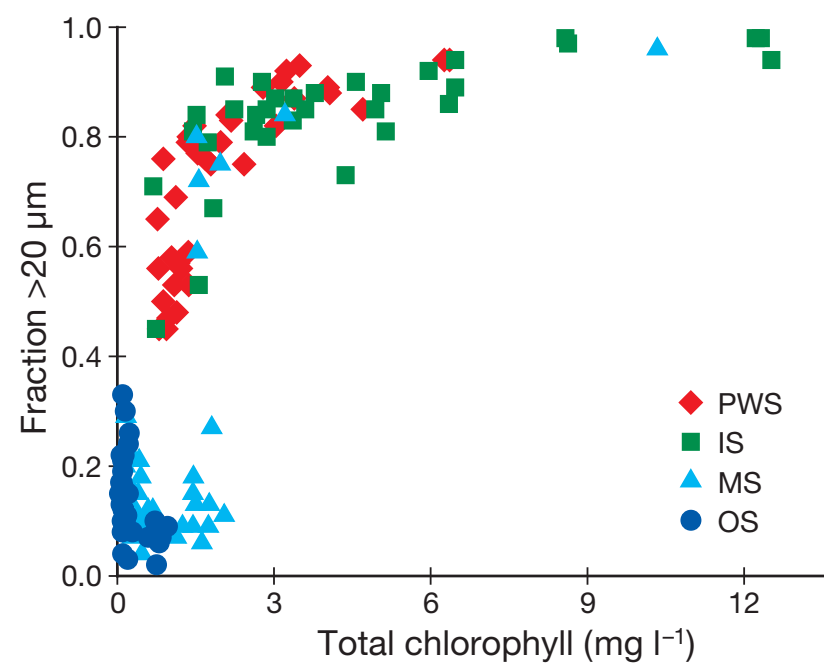

Fig. 4. Total chlorophyll concentrations vs. fraction of total in cells $>20 \mu \mathrm{m}$ during April, May and July 2001 cruises. Data are from $10 \mathrm{~m}$ or sampled depth nearest to $10 \mathrm{~m}$; core and grid station data combined. Site abbreviations as for Fig. 1 

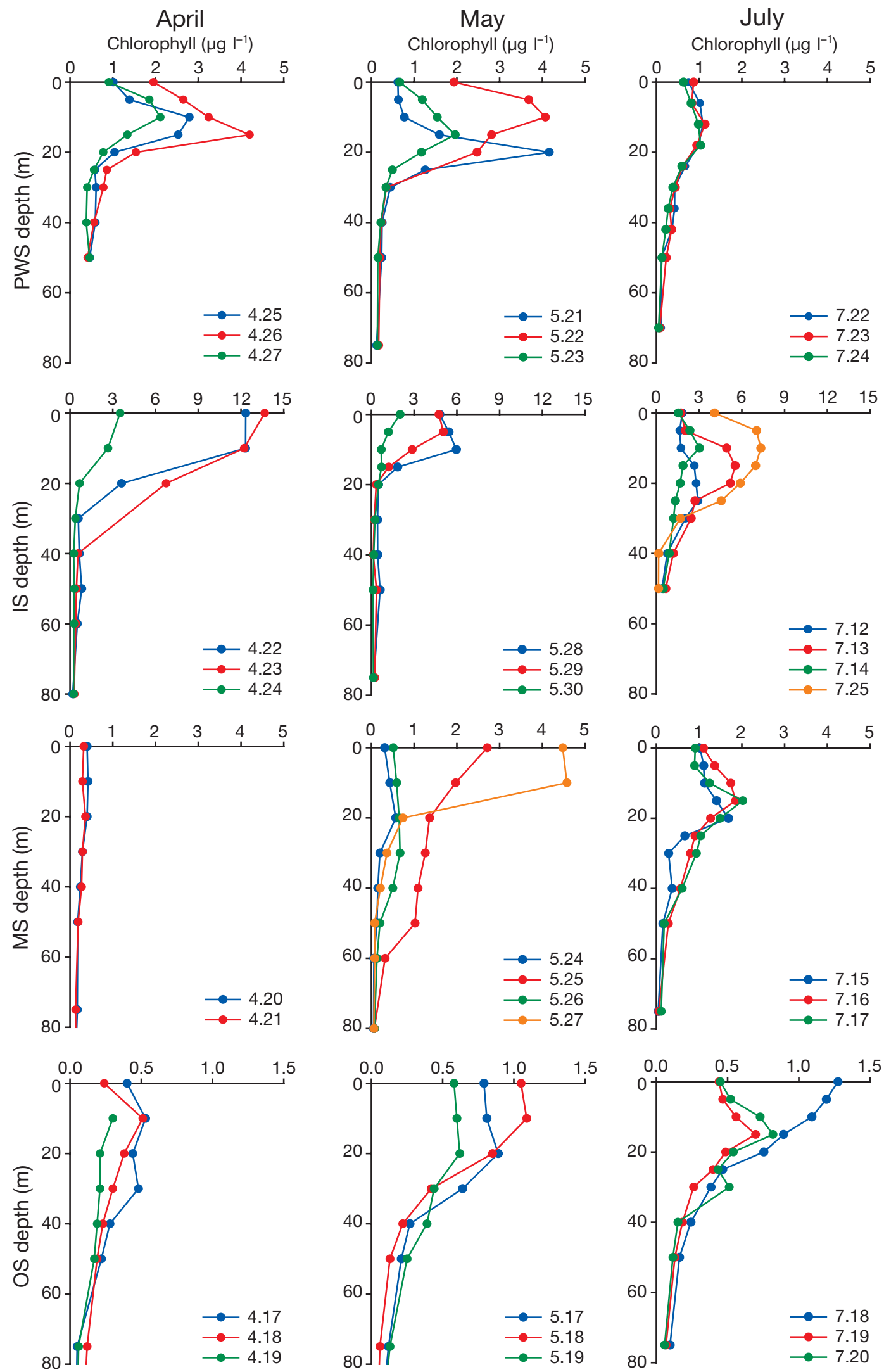

Fig. 5. Vertical profiles of total chlorophyll concentration for all core sampling dates (mo.d) during 2001 cruises. Note different chlorophyll scales for different shelf regions. Site abbreviations as for Fig. 1 
Timing of maximum chlorophyll levels and size composition of phytoplankton depended on cross-shelf location (Figs. 3 \& 5). Prince William Sound probably experienced annual maximum chlorophyll levels before our arrival, as the water column was strongly stratified and the SCM well-developed by the time of our late April sampling. In a previous study we observed an intense diatom bloom in PWS on 3 April (Strom et al. 2001). The large cell-dominated spring phytoplankton community here gave way to a July assemblage with reduced chlorophyll levels (Fig. 5) and roughly equal proportions of cells $<20$ and $>20 \mu \mathrm{m}$ (Table 2). On the inner shelf, consistently high chlorophyll levels were always due mainly to large cells (Figs. 4 \& 5), while the mid shelf was more variable, with a spatial mosaic of diatom bloom and small-cell dominated 'blue water' communities in May, and a moderate biomass of mostly small cells in July (Figs. 4 \& 5, Table 1). Except in April, outer shelf chlorophyll levels were always the lowest observed anywhere in the region (Figs. 3A \& 5), and phytoplankton there were mainly $<5 \mu \mathrm{m}$ in size (Figs. 3B \& 4).

\section{Nutrient utilization and phytoplankton species composition}

Upper water column nitrate:phosphate ratios show that, in the absence of other growth-limiting factors (see below), the CGOA overall is $\mathrm{N}$ - rather than P-limited. Phosphate concentrations were uniformly in excess of those predicted by the 16:1 Redfield N:P ratio (Fig. 6). Nitrate:phosphate relationships for each month and region show the earlier onset of spring production in PWS and the inner shelf where, assuming that winter surface nutrient levels were similar to those on the mid and outer shelf (as shown by Childers et al. 2005), substantial nutrient removal had occurred by the time of our April sampling. Nitrate and phosphate drawdown on the mid and outer shelf were slight before May. Nitrate:phosphate utilization ratios decreased with time in all regions, indicating an increased dependence of phytoplankton production on regenerated nitrogen sources in summer relative to spring (Table 4).

Patterns of silicic acid utilization also showed a distinct gradient from outer to inner shelf in the CGOA. On the outer shelf, large decreases in nitrate were associated with much smaller reductions in silicic acid so that, by July, low surface layer nitrate levels were accompanied by substantial (5 to $17 \mu \mathrm{M}$ ) residual silicic acid concentrations (Fig. 7A). Note that it is inappropriate to calculate silicic acid:nitrate utilization ratios for the outer shelf, since most of the phytoplankton there were not diatoms (see 'Materials and methods'). On the mid and inner shelf, spring utilization of silicic acid and nitrate were more closely matched, with spring utilization ratios of 1.77 on the mid shelf and 1.78 to 1.83 on the inner shelf (Fig. 7B,C, Table 4). Elevated summer silicic acid concentrations on the mid shelf and, to a lesser extent, on the inner shelf (green circles in Fig. 7B,C) indicate transport of surface waters from further offshore, as has been reported for this region (Stabeno et al. 2004). The spring utilization ratio in PWS ranged from 0.99 to 1.37 , lower than that on the shelf and indicative of nearly equimolar use of nitrate and silicic acid (Fig. 7D, Table 4). Despite the greater spring utilization of nitrate relative to silicic acid, July residual silicic acid concentrations in PWS were lower than any on the shelf, ranging from 0.1 to $2.0 \mu \mathrm{M}$ (average $1.0 \mu \mathrm{M}$ ). This may indicate reduced input of dissolved Si-rich offshore waters to PWS relative to the mid and inner shelf in summer.

The high residual silicic acid concentrations on the outer shelf were reflected in the phytoplankton taxonomic composition there. Diatoms were undetectable in April samples; in May and July, only needleshaped pennate taxa (species of Cylindrotheca, Thalassionema, Pseudo-nitzschia) were found; these cells were sparse and appeared lightly silicified. Instead, as reflected in the chlorophyll sizefractionation data (Fig. 4), the community was dominated by small autotrophic flagellates and Synechococcus spp. In contrast, mid and inner shelf diatom blooms were dominated by large-celled, centric, chain-forming genera. Thalassiosira spp. predominated in April and various Chaetoceros species in May, although a mix of species was always present. By July, chain-forming diatoms still dominated on the

Table 4. Nutrient utilization ratios (molar) derived from water column samples (upper $20 \mathrm{~m}$ ) taken during 2001 grid and core station sampling in coastal Gulf of Alaska (see Figs. 6 \& 7). nd: ratios not calculated because community was not dominated by diatoms (silicic acid:nitrate) or because changes in concentration during sampling period were $<2 \mu \mathrm{M}$ (nitrate:phosphate). See 'Materials and methods' for details. PWS: Prince William Sound

\begin{tabular}{|lcccc|}
\hline Nutrient & Outer shelf & Mid shelf & Inner shelf & PWS \\
\hline $\mathbf{S i}(\mathbf{O H})_{4}: \mathbf{N O}_{3}$ & & & & \\
April & nd & nd & 1.83 & 1.37 \\
May & nd & 1.77 & 1.78 & 0.89 \\
July & nd & nd & 1.65 & nd \\
NO $_{3}: \mathbf{P O}_{4}$ & & & & \\
April & nd & nd & 14.1 & 12.4 \\
May & 16.8 & 13.2 & 11.7 & 9.4 \\
July & 12.0 & 11.4 & 8.5 & 10.2 \\
\hline
\end{tabular}



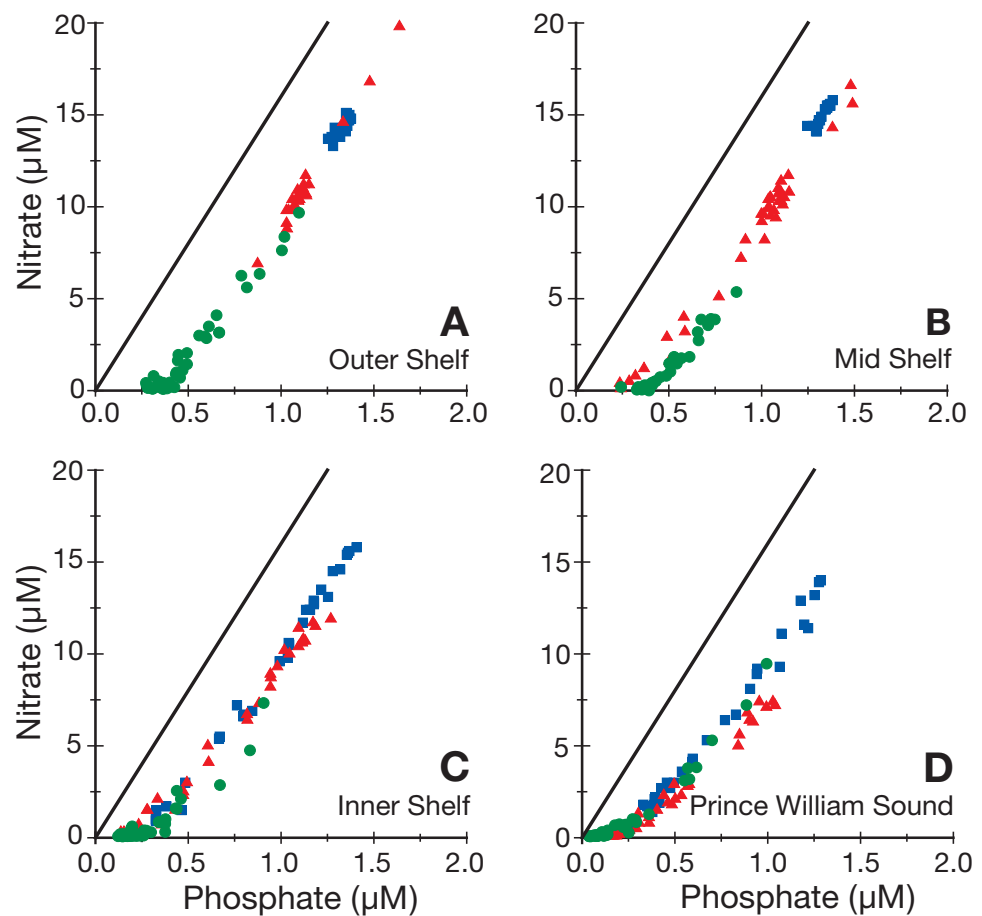

Fig. 6. Relationships between nitrate and phosphate concentrations in upper $20 \mathrm{~m}$ at core and grid stations on (A) outer shelf, (B) mid shelf, (C) inner shelf and (D) in Prince William Sound. Continuous lines show Redfield ratio of 16:1; nitrate:phosphate utilization ratios for individual

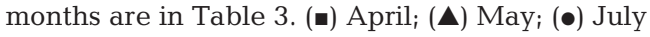
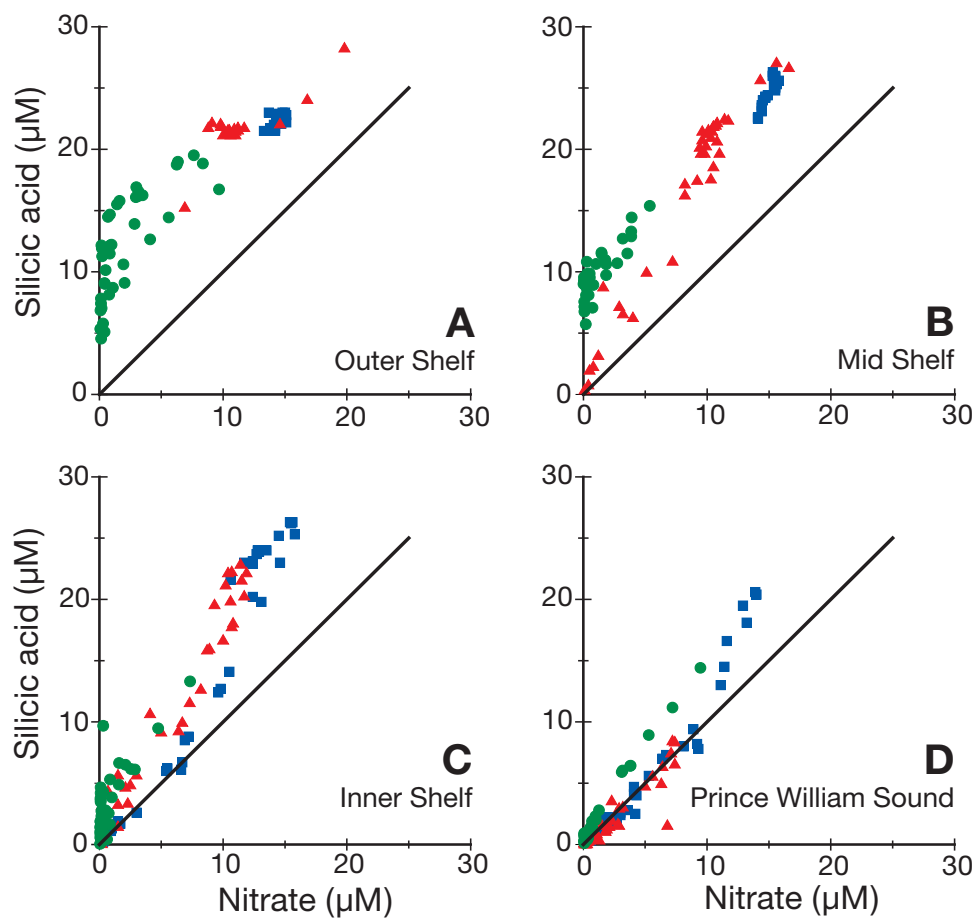

Fig. 7. Relationships between silicic acid and nitrate concentrations in upper $20 \mathrm{~m}$ at core and grid stations on (A) outer shelf, (B) mid shelf, (C) inner shelf and (D) in Prince William Sound. Continuous lines show 1:1 ratios; silicic acid:nitrate utilization ratios for individual months are in Table 3. Symbols as in Fig. 6 inner shelf, while the mid shelf supported a lower biomass community dominated by autotrophic flagellates and Synechococcus spp. In PWS we observed a diverse community dominated by various centric and pennate diatom taxa beginning in April.

\section{Phytoplankton growth rate and nutrient limitation}

Most of the highest intrinsic growth rates that we observed were associated with the diatom bloom communities of the inner and (in May) mid shelf (Figs. 8 to 11). Small-cell dominated communities of the mid shelf also sometimes exhibited high rates of growth. Nutrient limitation was common in both types of communities during May and July. On 11 out of 14 dates, growth rates in at least 1 chlorophyll size fraction increased significantly in response to $\mathrm{N}+\mathrm{P}$ addition (Figs. 10 \& 11). In contrast, growth rates in PWS and on the outer shelf were mainly low to moderate, and only sometimes (PWS) or never (OS) responded to added macronutrients (Figs. 9 \& 12).

The outer shelf community, predominantly $<5 \mu \mathrm{m}$ cells present at low biomass, showed low to moderate growth rates ranging from 0.11 to $0.88 \mathrm{~d}^{-1}$ across all size fractions and cruises. Average outer shelf growth rates for the whole community (i.e. total chlorophyll-based rates) were particularly low in May, averaging only $0.22 \mathrm{~d}^{-1}$ (Table 5), although macronutrient concentrations and light levels during these experiments were some of the highest we recorded in any season (Table 1). Outer shelf phytoplankton growth rates did not respond to nutrient addition (Fig. 9D to F, Table 5).

Growth rates on the mid shelf showed high variability, ranging from -0.59 to $1.21 \mathrm{~d}^{-1}$ across all size fractions and cruises. Spring growth was mostly moderate to high, with no clear relationship to community type. For example, rates $>1 \mathrm{~d}^{-1}$ were measured in the small-cell dominated blue-water communities of 21 April and 24 May, while equally high rates were observed in the diatom bloom on 25 May (Figs. 8 \& 10). Cells $>5 \mu \mathrm{m}$ in the 27 May bloom located west of the Seward Line were dying in the incubation bottles (i.e. 

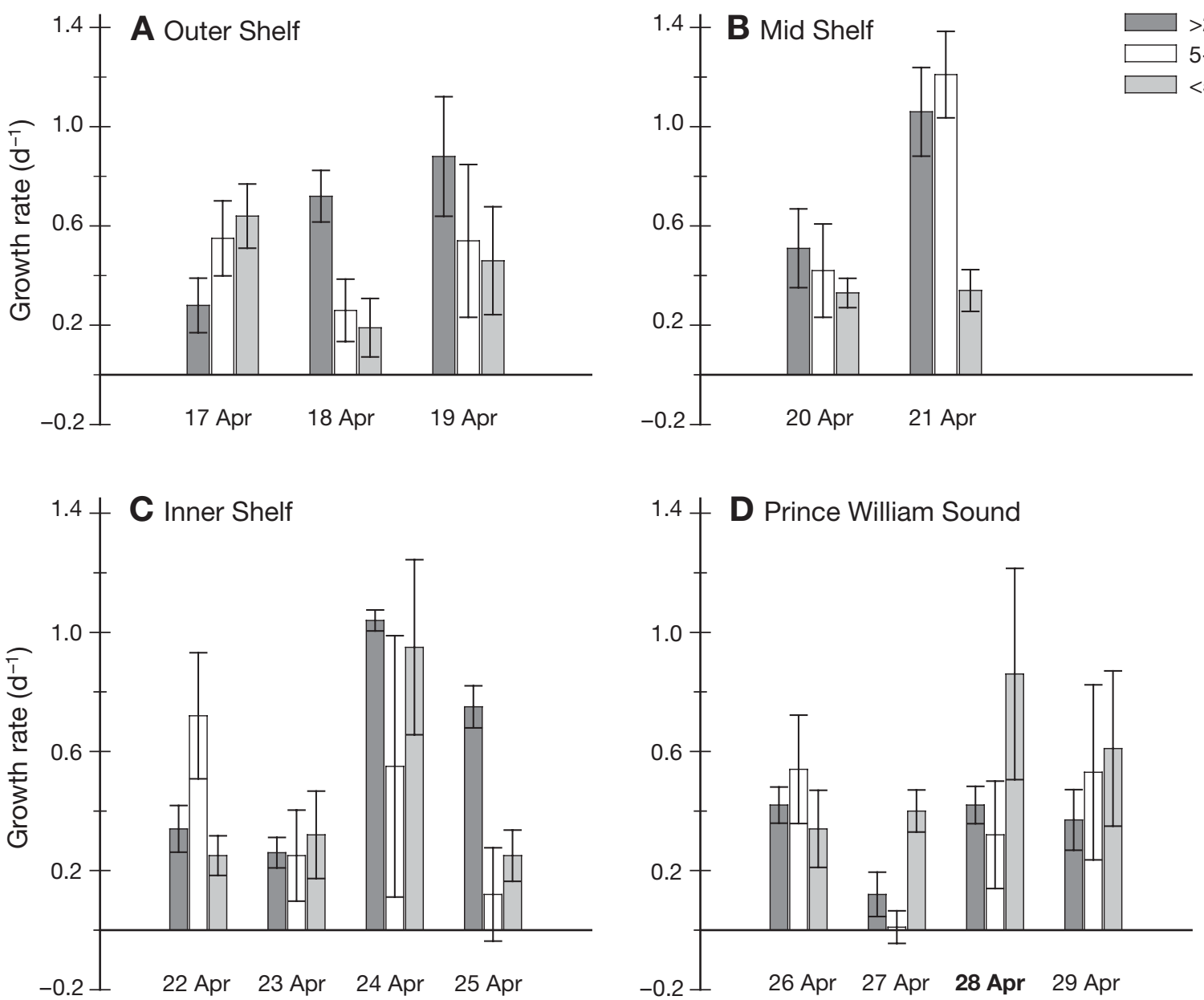

Fig. 8. Intrinsic growth rates of phytoplankton in 3 size fractions at (A) outer shelf, (B) mid shelf, (C) inner shelf, and (D) Prince William Sound regions during April 2001. Error bars: \pm 1 SE from regression estimates of growth rate. 28 April (bold) was subsurface chlorophyll maximum experiment, all other dates were experiments from depth corresponding to $50 \%$ surface irradiance

intrinsic growth rates were negative) and showed only a weak response to added macronutrients, indicating a senescent diatom community (Fig. 10). Low ambient growth rates in July mid shelf experiments showed a strong response to added nutrients across all size fractions (Fig. 10D-F): average rates for total chlorophyll increased from 0.10 to $0.73 \mathrm{~d}^{-1}$ in response to $\mathrm{N}+\mathrm{P}$ addition (Table 5).

We encountered diatom blooms in inner shelf ACC waters on all 3 cruises (Fig. 5). These diatoms responded strongly to added nutrients (Table 5) and sustained high rates of growth when supplied with sufficient macronutrients, either by nature (e.g. on 30 May when a water mass with elevated nitrate levels entered the region, Table 1) or experimentally (Fig. 11). In contrast, unenriched growth rates of $<5$ and 5-20 $\mu \mathrm{m}$ phytoplankton in these waters were often low $\left(<0.4 \mathrm{~d}^{-1}\right)$ and, in any given experiment, showed a weaker response to added nutrients than the $>20 \mu \mathrm{m}$ fraction (Fig. 11).
Thus the range of growth rates across all size fractions and cruises was quite broad for the inner shelf, $\left(-0.09\right.$ to $\left.1.14 \mathrm{~d}^{-1}\right)$.

Growth rates in PWS tended to be lower than those on the mid and inner shelf, especially in spring (Table 5). While the overall range of rates across all size fractions and cruises was -0.06 to $1.14 \mathrm{~d}^{-1}$ (similar to the range on the inner shelf), rates exceeding $1.0 \mathrm{~d}^{-1}$ were measured on only one occasion (24 July, $<5 \mu \mathrm{m}$ fraction, Fig. 12F). Overall, PWS growth rates in July were higher than those in spring (Table 5), although July surface nutrient levels were very low. In further contrast to the mid and inner shelf, the response to nutrient addition in PWS was usually modest. For example, in the two July $50 \% I_{0}$ experiments, mixed layer nitrate concentrations were $<0.5 \mu \mathrm{M}$, yet the only significant response to added $\mathrm{N}+\mathrm{P}$ was a modest increase in growth of the largest cells on July 24 (Fig. 12D-F). 

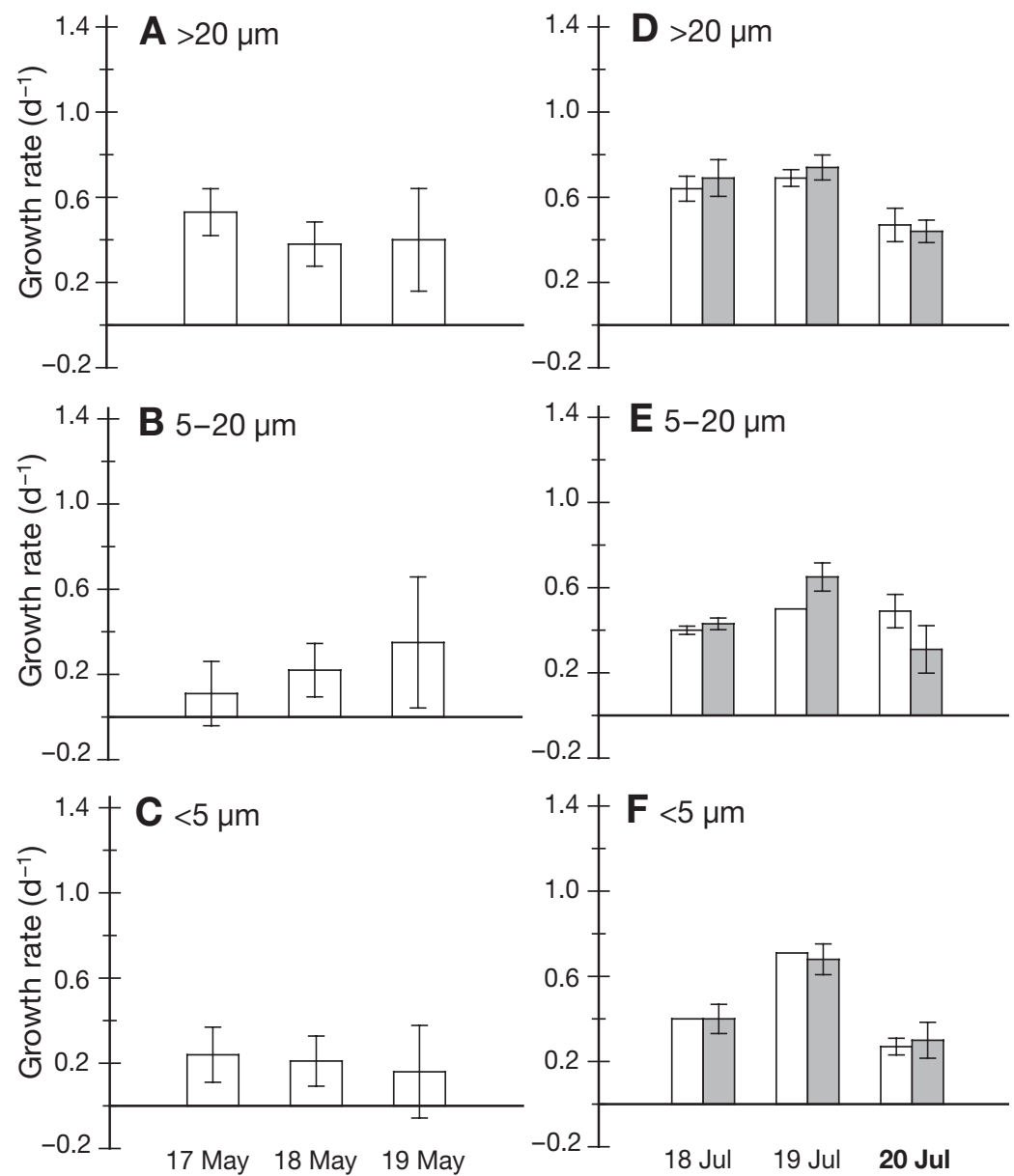

Fig. 9. Intrinsic growth rates of 3 size fractions of outer shelf phytoplankton in (A, B, C) May and (D, E, F) July 2001. Open bars: growth rates in unenriched bottles; shaded bars: growth rates in bottles enriched with nitrate and phosphate. Error bars show 95\% confidence interval from regression analysis of dilution series (enriched rates) or from duplicate undiluted bottles (unenriched rates). 20 July (bold) was subsurface chlorophyll maximum experiment, all other dates are experiments from depth corresponding to $50 \%$ surface irradiance

\section{DISCUSSION}

\section{Macronutrient limitation of phytoplankton growth}

Light has been hypothesized to be the primary limiting resource for phytoplankton production in high latitude ecosystems such as the CGOA (Gargett 1997). Our data, however, show that macronutrient limitation of phytoplankton growth is a hallmark of spring and summer production on the mid and inner shelf. Similar findings have been reported for coastal regions farther south in the Gulf of Alaska (Harrison et al. 1983, Whitney et al. 2005). Although we did not separately examine nitrate and phosphate limitation in our experiments, excess upper water column concentrations of $\mathrm{P}$ relative to $\mathrm{N}$ (Fig. 6) indicate that nitrogen was likely to have been the proximate growth-enhancing nutrient in our additions. With this assumption, and excluding SCM experiments, 5 out of 6 sampling dates on both mid and inner shelf revealed $\mathrm{N}$ limitation of phytoplankton growth rate (Figs. 10 \& 11). Growth in PWS was also N-limited on some occasions in May. By July, however, nutrient addition had no effect on PWS growth rates, despite surface nitrate concentrations $<0.5 \mu \mathrm{M}$ (Fig. 12). We hypothesize that the greater physical stability of the PWS water column allows development of a summer community sustained by regenerated nitrogen, so that summer $\mathrm{N}$ limitation was not evident here as it was on the mid and inner shelf. This interpretation is supported by the nitrate:phosphate utilization ratios. The removal of phosphate without accompanying changes in nitrate when overall nutrient levels were low indicates reliance on regenerated $\mathrm{N}$ for phytoplankton growth under these conditions (Fig. 6D). Behavioral and nutritional strategies of planktonic organisms could also play a role in the resource response of the community. For example, we observed high summer concentrations of Ceratium spp. in PWS; this taxon can vertically migrate between surface and pycnocline waters to obtain light and nutrients from separate depth strata (Figueroa et al. 1997).

Although the April experiments were not nutrient-enriched, there was almost certainly some degree of nutrient limitation in the ACC and PWS at this time. There are several lines of evidence for this. First, the increase in growth rates on the inner shelf between 23 and 24 April (Fig. 8C) was associated with the arrival of a water mass containing higher surface macronutrient levels (3.0 vs. $13.5 \mu \mathrm{M}$ nitrate; 2.6 vs. $24.0 \mu \mathrm{M}$ silicic acid; Table 1). Second, across the whole April ecosystem, we observed the lowest growth rates in PWS (Table 5), where surface nutrient concentrations were the lowest (Table 1). Finally, late April experiments conducted in 2003 (data not shown) showed a growth rate response to added nutrients at some inshore stations, demonstrating that this season, in general, is not too early for the onset of nutrient limitation. Spring stratification in the ACC is initiated by salinity reductions as early as April (Weingartner et al. 2005). In some years, nitrate levels in the ACC are by this time drawn down from winter maxima to near zero (Childers et al. 2005). Our data show that nutrient limitation of phytoplankton growth 
rates quickly follows the onset of spring stratification in the CGOA and the resulting phytoplankton bloom, and characterizes much of the spring diatom bloom community as well as the summer period of shelf-wide stratification.

As described in the 'Introduction', the CGOA experiences a range of physical processes that result in advection and mixing of water masses. Given the widespread spring and summer nitrogen limitation that we observed, such events have the potential to affect phytoplankton production on a range of scales. We saw evidence for this in our rate measurements. For example, day-to-day changes in growth rates and nutrient limitation of ACC phytoplankton (Figs. 8C \&
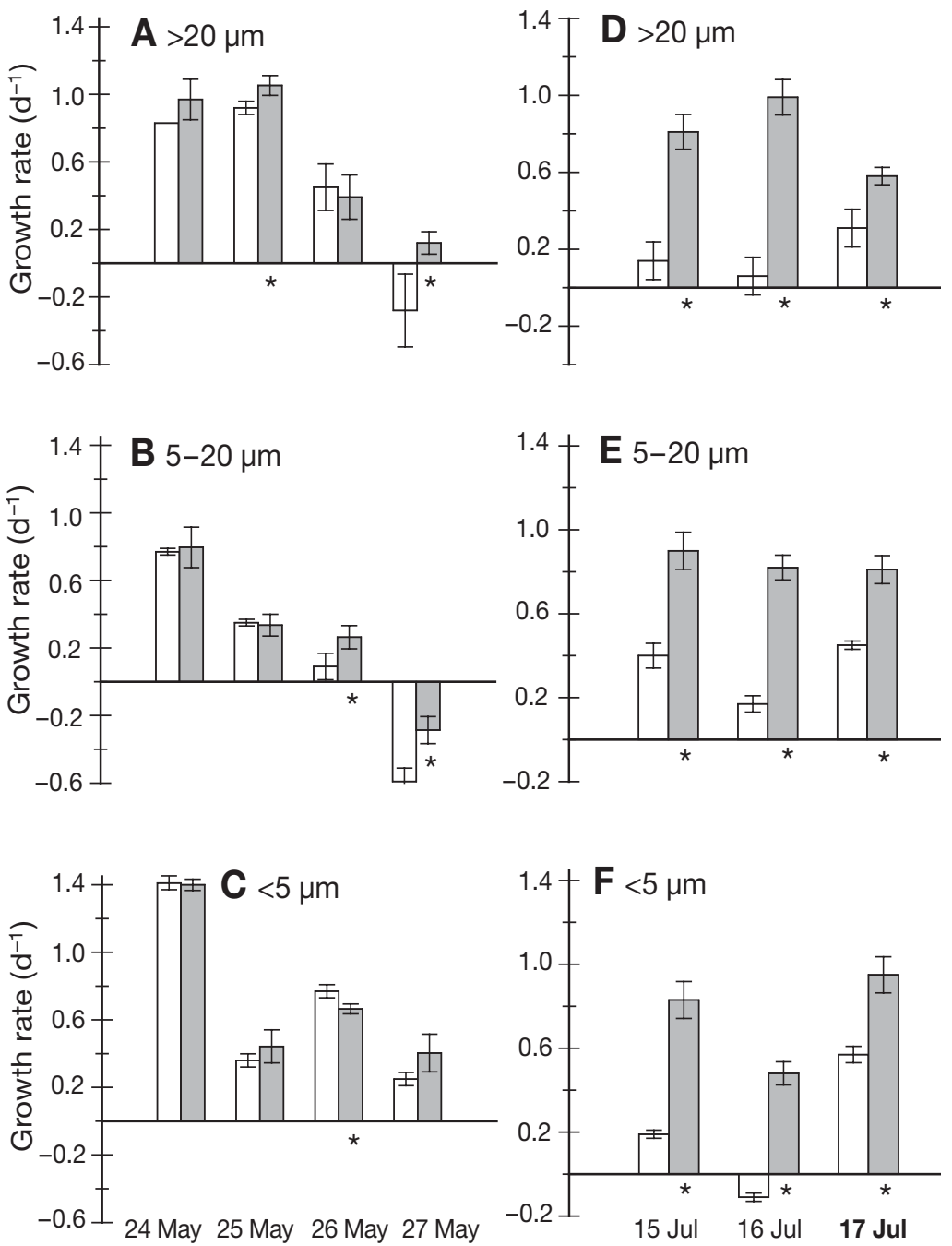

Fig. 10. Intrinsic growth rates of 3 phytoplankton size fractions for mid shelf region. *Experiments with significant differences between unenriched (open bars) and nutrient-enriched (shaded bars) growth rates ( $\mathrm{p}<$ 0.05). Note different scales of $y$-axes between months. 17 July (bold) was subsurface chlorophyll maximum experiment, all other dates are experiments from depth corresponding to $50 \%$ surface irradiance
11A-C) were associated with horizontal advection past our study site of water masses containing different macronutrient concentrations. This suggests shortterm variations in physical processes affecting the ACC in the region east (upstream) of the Seward Line. The intense summer diatom bloom that we observed in the ACC, apparent during both mid and late July (Fig. 5, Table 1), may have been associated with upwelling events that occurred prior to and during our summer cruise (Fig. 2).

In general, intermittent mixing events that supply nutrients to the surface through the relatively shallow pycnocline, followed by stratification to allow lightdriven utilization of those nutrients, may promote the highest levels of primary productivity in the CGOA. This scenario would both optimize the availability of resources to the phytoplankton (thereby increasing growth rates) and, by repeatedly disturbing the environment and changing the composition of the phytoplankton community, tend to uncouple primary production from immediate consumption by microzooplankton grazers (thereby increasing biomass; see Strom et al. in press). Thus, the frequency of physical events, particularly in spring and summer, may be as important as their intensity. Climate indices such as the PDO are based on the average state of the system and do not effectively capture year-to-year variations in event frequency and timing. Stabeno et al. (2004) found that, even on a purely physical level, the relationship between the PDO and conditions in the CGOA was quite weak, with most of the meteorological and oceanographic variability in the CGOA occurring on seasonal and shorter time scales. An analysis of how multi-year regimes such as the PDO influence physical variability on subseasonal time scales appears necessary to relate primary production responses in the CGOA to longer-term, regime-associated variations in stocks of fishes and marine mammals.

\section{Cross-shelf gradients in phytoplankton community structure and processes}

While inputs of macronutrients are clearly important for stimulating spring and summer production in the CGOA, macronutrient availability does not explain the persistent cross-shelf gradients that we observed in phytoplankton community structure, bio- 

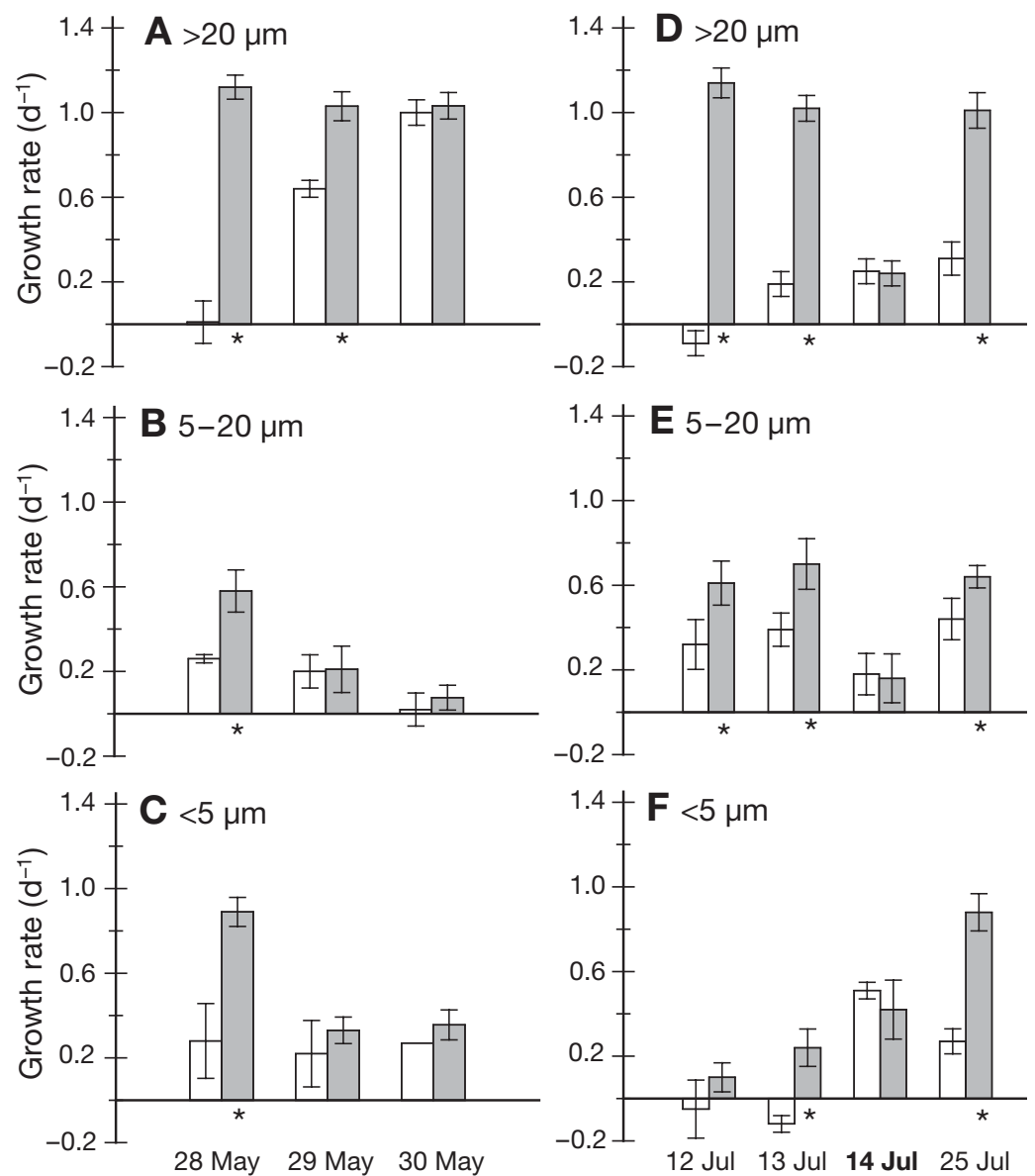

Fig. 11. Intrinsic growth rates of 3 phytoplankton size fractions for inner shelf region. ${ }^{*}$ Experiments with significant differences between unenriched (open bars) and nutrient-enriched (shaded bars) growth rates $(\mathrm{p}<0.05)$. 14 July (bold) was subsurface chlorophyll maximum experiment, all other dates are experiments from depth corresponding to $50 \%$ surface irradiance
(Boyd et al. 1996, 2004). Primary production levels are suppressed by a combination of physiological limitation (through iron limitation effects on photosynthesis and macronutrient utilization) and low phytoplankton biomass (due to micrograzer removal of small phytoplankton cells), giving rise to a persistently 'high-nitrate, low-chlorophyll' (HNLC) ecosystem (Miller et al. 1991). To the north, glaciated mountains surrounding the CGOA supply large amounts of freshwater and suspended sediments to the inner shelf. There is some indication that both freshwater and terrigenous sediments are high in iron (Feely et al. 1981, Stabeno et al. 2004).

In addition to the geography of the region, numerous features of the shelf phytoplankton community are consistent with an inshore-offshore gradient in iron availability. Small phytoplankton cells and low phytoplankton biomass characterized the outer shelf as well as the summer mid shelf during all 3 of our cruises: chronic iron limitation favors small cells because their larger surface area:volume ratio gives them a competitive advantage when nutrient availability is low (Hudson \& Morel 1993). Silicic acid utilization was severely restricted on the outer shelf as well, with high residual silicic acid levels when nitrate was fully depleted. These nutrient use patterns were reflected in the low abundance of diatoms and the presence of mainly small-celled, pennate taxa among those diatoms that were present mass, growth rate, and macronutrient utilization. These cross-shelf patterns, when considered together, are consistent with a cross-shelf gradient in the availability of dissolved iron, an essential micronutrient for phytoplankton production. Below we establish the case for an ecosystem-structuring gradient in dissolved iron availability by reference to each of the above features of the phytoplankton community, plus information about the environmental context.

The open subarctic Pacific, source of surface water to the shelf during downwelling events, is known to have very low dissolved iron concentrations in the mixed layer (<2 nM, Martin et al. 1989). These low-iron surface waters were shown to extend onto the outer shelf in the vicinity of the Seward Line (Martin et al. 1989). Bottle incubation and in situ fertilization experiments have demonstrated that limited iron availability in the open subarctic ecosystem restricts the phytoplankton community to small-celled, primarily non-diatom taxa
Table 5. Average (SD) growth rate $\left(\mathrm{d}^{-1}\right)$ of total chlorophyll from seawater dilution experiments during 2001. Only data from $50 \%$ surface irradiance experiments are included (see Table 1); unenriched: no nutrients added; $+\mathrm{N}+\mathrm{P}$ : nitrate and phosphate added; nd: not determined

\begin{tabular}{|lccc|}
\hline Area & April & May & July \\
\hline $\begin{array}{l}\text { Outer shelf } \\
\text { unenriched } \\
+\mathrm{N}+\mathrm{P}\end{array}$ & $\begin{array}{c}\text { (1) }(0.19) \\
\text { nd }\end{array}$ & $\begin{array}{c}0.22(0.01) \\
\text { nd }\end{array}$ & $0.52(0.20)$ \\
$\begin{array}{l}\text { Mid shelf } \\
\text { unenriched }\end{array}$ & $0.43(0.18)$ & $0.63(0.20)$ \\
$+\mathrm{N}+\mathrm{P}$ & nd & $0.74(0.50)$ & $0.73(0.19)$ \\
$\begin{array}{l}\text { Inner shelf } \\
\text { unenriched }\end{array}$ & $0.57(0.32)$ & $0.52(0.37)$ & $0.11(0.19)$ \\
$+\mathrm{N}+\mathrm{P}$ & nd & $0.97(0.09)$ & $0.92(0.13)$ \\
$\begin{array}{l}\text { Prince William Sound } \\
\text { unenriched }\end{array}$ & $0.36(0.15)$ & $0.27(0.06)$ & $0.62(0.11)$ \\
$+\mathrm{N}+\mathrm{P}$ & nd & $0.52(0.07)$ & $0.75(0.25)$ \\
\hline
\end{tabular}



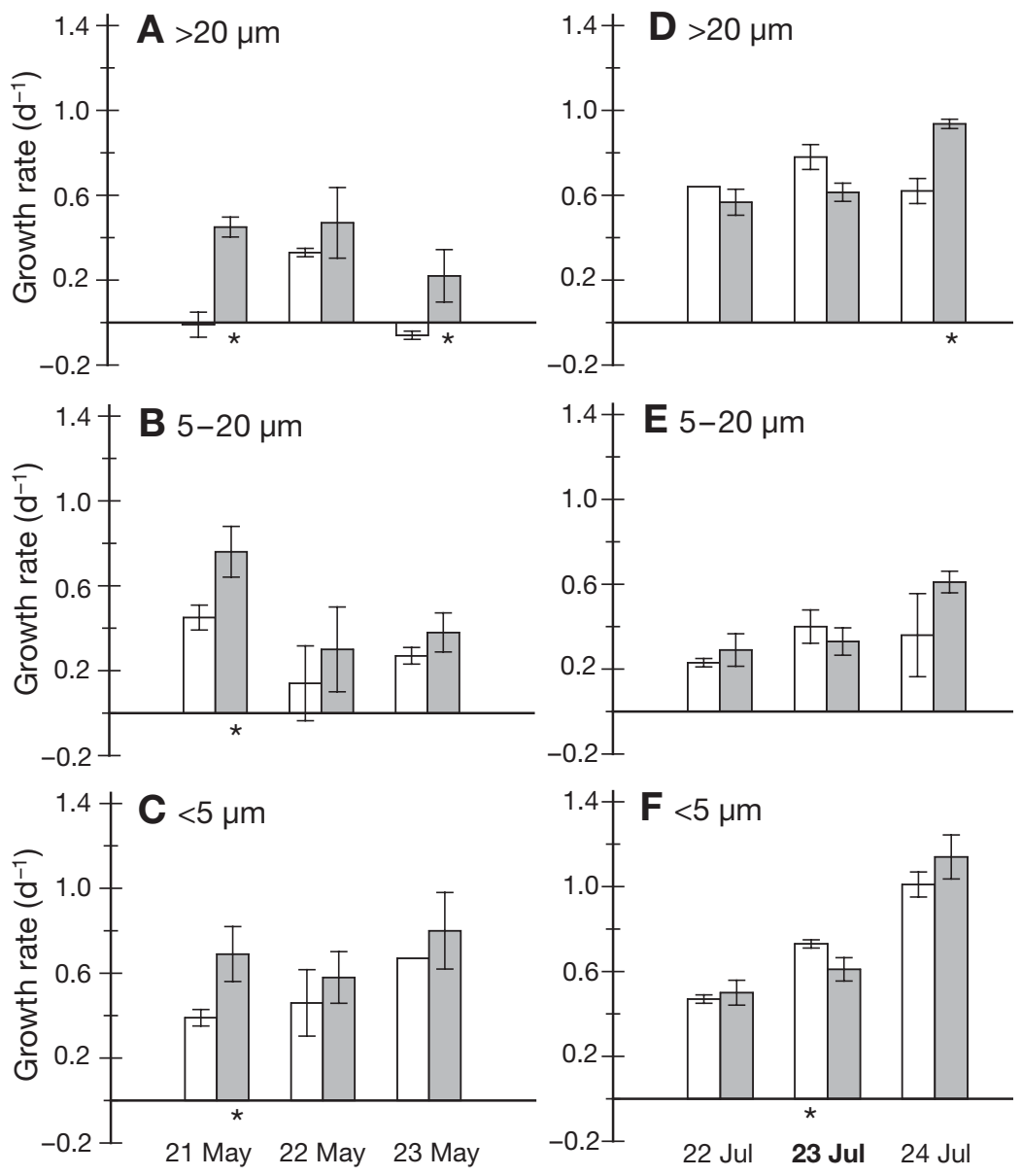

Fig. 12. Intrinsic growth rates of 3 phytoplankton size fractions for Prince William Sound. *Experiments with significant differences between unenriched (open bars) and nutrient-enriched (shaded bars) growth rates $(p<0.05)$. 23 July (bold) was subsurface chlorophyll maximum experiment, all other dates are experiments from depth corresponding to $50 \%$ surface irradiance

(summer only). Limitation of diatom production is characteristic of severely iron-limited marine ecosystems (Gall et al. 2001, Boyd et al. 2004, Coale et al. 2004). Finally, the growth rate data for July OS phytoplankton are indicative of strong growth limitation by a resource other than macronutrients. Nitrate levels in the 19 July experiment were only $0.2 \mu \mathrm{M}$, well below the half-saturation constant for most marine phytoplankton species (Smayda 1997), yet we observed no growth rate response to the added $\mathrm{N}+\mathrm{P}$. While our collection and enrichment methods surely introduced iron into the experiments, a $24 \mathrm{~h}$ incubation is probably less than the time required for a chlorophyll biomass increase in response to added iron (Boyd et al. 1996, Hutchins \& Bruland 1998).

It could be argued that the lack of growth response of the summer OS community is unrelated to Fe limitation, but rather is due to the time required to synthe- size and activate nitrate reductase for utilization of the added nitrate. A comparison of the 19 July outer shelf experiment with the July 15 and 16 mid shelf experiments indicates, however, that nitrate limitation of the outer shelf is unlikely. All 3 experiments had very low nitrate levels $(<0.3 \mu \mathrm{M}$, Table 1$)$, and were nearly identical in terms of phytoplankton biomass (0.98 to $1.07 \mu \mathrm{g}$ chlorophyll $\mathrm{l}^{-1}$ ) and size composition (67 to $78 \%$ of chlorophyll in cells $<5 \mu \mathrm{m}$, Table 2). Despite this similarity, the mid shelf summer community showed a rapid and strong growth response to added nitrate (Fig. 10D-F) while the outer shelf community did not (Fig. 9D-F). Given the potential for these offshore communities to respond rapidly to added nitrate, we consider the lack of response on the outer shelf, in combination with reduced silicic acid use and phytoplankton community structure, to be indicative of $\mathrm{Fe}$ limitation of phytoplankton growth.

Although the outer shelf exhibited many features consistent with iron limitation, this region was not an HNLC system in 2001. Nitrate levels declined to near zero during summer (Fig. 6A) and we measured chlorophyll concentrations as high as $1.3 \mu \mathrm{g} \mathrm{l}^{-1}$. Furthermore, substantial blooms have sometimes been observed over the outer shelf, indicating that physical processes episodically deliver limiting nutrients to the region (Strom et al. 2001; Childers et al. 2005). We postulate that the CGOA outer shelf is intermediate, in terms of iron availability, between the HNLC waters of the open subarctic and the nearshore waters of the inner shelf.

In contrast, the CGOA inner shelf and PWS showed few, if any, signs of iron limitation. Blooms comprising a high biomass of large-celled chain diatoms were common, and resulted in depletion of nitrate and silicic acid. Culture studies have shown that fully ironreplete diatoms use silicic acid and nitrate, on average, with a ratio of 1:1 (Brzezinski 1985). Elevated silicic acid:nitrate utilization ratios of $2: 1$, similar to those we observed on the mid and inner shelf in spring, have been interpreted as evidence of low-level iron limitation in other coastal ecosystems (Hutchins \& Bruland 1998, Hutchins et al. 1998, Firme et al. 2002). However, differences in phytoplankton species composition could also give rise to different community nutrient utilization ratios. 
The influence of physical events and long-term climate regimes on delivery of iron as a limiting resource depend critically on the nature of the dissolved iron sources to the CGOA. Little is known about these sources, which may include deep waters (important along the California coast, Bruland et al. 2001), riverine inputs, and atmospheric dust (Boyd et al. 1998). The timing of iron input from these sources and the degree of accompanying macronutrient enrichment will differ considerably, with consequences for the level of phytoplankton production that can be realized. Stabeno et al. (2004) hypothesized that a key to the high productivity of the CGOA shelf may lie in the mixing of ocean waters high in nitrate and silicic acid with highiron, low macronutrient run-off from the Alaska continent, through various cross-shelf exchange processes.

\section{Multiple limitations on primary production, and implications for modeling and prediction}

We used stepwise multiple regression (SPSS Version 12.0; Chatterjee et al. 2000) to examine the simultaneous effects of temperature, light, nitrate concentration, and location on phytoplankton growth rates (all cruises combined) for each of the 3 chlorophyll size fractions (Table 6). The lack of a temperature effect is evident in the data: highest growth rates in April equaled even the highest nutrient-enriched rates in July (cf. Figs. $8 \& 11$ ), although April surface waters were 6 to $8^{\circ} \mathrm{C}$ colder (Table 1). For $>20 \mu$ m phytoplankton, only nitrate was predictive of growth rate and the relationship was weak, explaining only $26 \%$ of the variation in rates (Table 6). For phytoplankton 5 to $20 \mu \mathrm{m}$ in size, light plus nitrate significantly (but again weakly) predicted growth rate; curiously, light intensity was inversely related to growth rate for this size fraction. None of the variables could be fit to $<5 \mu \mathrm{m}$ phytoplankton growth rates, even when the significance level was relaxed to 0.10 .

We believe that the weak relationship between phytoplankton growth rate and the environmental variables examined here is due to the mosaic of resource availability in the CGOA. For example, low growth rates were observed on both the inner shelf (due to nitrogen limitation) and on the outer shelf (attributed to iron limitation). Thus, low growth rates shelf-wide were not consistently associated with either cross-shelf location or with nitrate availability. Furthermore, communities in different shelf regions are adapted to local conditions and thus differ considerably in their taxonomic composition. Even under resourcereplete conditions, the flagellate and Synechococcus spp.-dominated community of the outer shelf might not have been capable of growth rates as high as the
Table 6. Results of stepwise regression of temperature (surface water temperature during incubation), nitrate (concentration in initial, pooled, whole seawater carboy, or in mixed layer sample collected nearest in time to experiment water), light (incident irradiance received during $24 \mathrm{~h}$ incubation) and location (OS, MS, IS, PWS: abbreviations as in Table 1) on unenriched growth rates in different phytoplankton size fractions (see Table 1). Only data from $50 \%$ surface irradiance experiments were included; data from all regions and months pooled for analysis. None of the variables was a significant predictor of $<5 \mu \mathrm{m}$ phytoplankton growth rates. Adj.: adjusted; SC: standardized coefficient

\begin{tabular}{|cccccc|}
\hline $\begin{array}{c}\text { Size fraction } \\
\text { predictor }\end{array}$ & $\begin{array}{c}\text { Adj. } \\
\mathrm{r}^{2}\end{array}$ & SE & SC & $p$ & $n$ \\
\hline $\begin{array}{c}\mathbf{2 0} \boldsymbol{\mu m} \\
\text { nitrate }\end{array}$ & 0.257 & 0.314 & 0.532 & 0.002 & 30 \\
$\mathbf{5 - 2 0} \boldsymbol{\mu m}$ & & & & & 30 \\
$\begin{array}{l}\text { light } \\
\text { nitrate }\end{array}$ & 0.244 & 0.258 & -0.418 & 0.016 & \\
\hline
\end{tabular}

diatom-dominated community of the inner shelf. In short, no simple model of limitation by a single resource will be sufficient to predict the response of CGOA phytoplankton to physical events and climate regimes. An understanding of how environmental gradients give rise to different phytoplankton community types and resource responses will be necessary. In predicting how environmental regulation of phytoplankton production will affect animals at higher trophic levels, we will also need to account for the differing fates of these various phytoplankton communities (e.g. sinking, grazing by micro- versus mesozooplankton; Strom et al. in press). The challenge for models that seek to predict how shelf production will respond to environmental variation is to define habitats occupied by functional groups within the shelf-wide community, identify the biological attributes and temporal stability of these groups, and understand their range of responses to environmental conditions.

Acknowledgements. We thank D. Erenstone, M. J. Zirbel, F. Perez, K. Bright, D. Lawrence, E. Close, W. Williams, M. Sookmi, D. Dukhovskoy, and G. Blamey for help on 2001 process cruises. Captain W. Rook and the crew of the RV 'Alpha Helix' were instrumental in the success of these cruises; we appreciate their effort and attitude. S. Danielson reprocessed the CTD data. This research was supported by NSF grant OCE 0101397 to S.S. Contribution number 292 from the US GLOBEC program, 2676 from PMEL, and 1049 from JISAO.

\section{LITERATURE CITED}

Armstrong FAJ, Stearns CR, Strickland JDH (1967) The measurement of upwelling and subsequent biological processes by means of the Technicon AutoAnalyzer and associated equipment. Deep-Sea Res 14:381-389 
Atlas EL, Callaway JC, Tomlinson RD, Gordon LI, Barstow L, Park PK (1971) A practical manual for the use of the Technicon Autoanalyzer for nutrient analysis, revised. Oregon State University, Corvallis

Boyd PW, Muggli DL, Varela DE, Goldblatt RH, Chretien R, Orians KJ, Harrison PJ (1996) In vitro iron enrichment experiments in the NE subarctic Pacific. Mar Ecol Prog Ser 136:179-193

Boyd PW, Wong CS, Merrill J, Whitney F, Snow J, Harrison PJ, Gower J (1998) Atmospheric iron supply and enhanced vertical carbon flux in the NW subarctic Pacific: is there a connection? Global Biogeochem Cycles 12:429-441

Boyd PW, Law CS, Wong CS, Nojiri Y and 34 others (2004) The decline and fate of an iron-induced subarctic phytoplankton bloom. Nature 428:549-553

Brodeur RD, Ware DM (1992) Long-term variability in zooplankton biomass in the subarctic Pacific Ocean. Fish Oceanogr 1:32-38

Bruland KW, Rue EL, Smith GJ (2001) Iron and macronutrients in California coastal upwelling regimes: implications for diatom blooms. Limnol Oceanogr 46:1661-1674

Brzezinski MA (1985) The Si:C:N ratio of marine diatoms: interspecific variability and the effect of some environmental variables. J Phycol 21:347-357

Calkins DG (1986) Marine mammals. In: Hood DW, Zimmerman ST (eds) The Gulf of Alaska: physical environment and biological resources. US Department of Commerce, Washington, DC, p 527-558

Chatterjee S, Hadi AS, Price B (2000) Regression analysis by example, 3rd edn. Wiley, New York

Childers AR, Whitledge TE, Stockwell DA (2005) Seasonal and interannual variability in the distribution of nutrients and chlorophyll $a$ across the Gulf of Alaska shelf: 19982000. Deep-Sea Res II 52:193-216

Coale KH, Johnson KS, Chavez FP, Buesseler KO and 44 others (2004) Southern Ocean iron enrichment experiment: carbon cycling in high- and low-Si waters. Science 304: 408-414

Dore JE, Houlihan T, Hebel DV, Tien G, Tupas L, Karl DM (1996) Freezing as a method of sample preservation for the analysis of dissolved inorganic nutrients in seawater. Mar Chem 53:173-185

Firme GF, Hutchins DA, Bruland KW, Rue EL, Weeks DA (2002) Spatial and temporal variability in phytoplankton iron limitation along the California coast and consequences for $\mathrm{Si}, \mathrm{N}$, and $\mathrm{C}$ biogeochemistry. Global Biogeochem Cycles 17:1016, doi: 10.1029/2001GB001824

Feely RA, Massoth GJ, Landing WM (1981) Major- and traceelement composition of suspended matter in the northeast Gulf of Alaska: relationships with major sources. Mar Chem 10:431-453

Figueroa FL, Niell FX, Figueiras FG, Villarino ML (1997) Diel migration of phytoplankton and spectral light field in the Ría de Vigo (NW Spain). Mar Biol 130:491-499

Gall MP, Boyd PW, Hall J, Safi KA, Chang H (2001) Phytoplankton processes. Part 1. Community structure during the Southern Ocean Iron RElease Experiment (SOIREE). Deep-Sea Res II 48:2551-2570

Gallegos CL (1989) Microzooplankton grazing on phytoplankton in the Rhode River, Maryland: nonlinear feeding kinetics. Mar Ecol Prog Ser 57:23-33

Gargett A (1997) The optimal stability 'window': a mechanism underlying decadal fluctuations in North Pacific salmon stocks. Fish Oceanogr 6:109-117

Gordon LI, Jennings JCJ, Ross AA, Krest JM (1993) A suggested protocol for continuous automated analysis of seawater nutrients (phosphate, nitrate, nitrite and silicic acid) in the WOCE Hydrographic program and the Joint Global Ocean Fluxes study.Methods manual WHPO 91-1. WOCE Hydrographic Program Offece. Woods Hole Oceanographic Institution, Woods Hole, MA

Harrison PJ, Fulton JD, Taylor FJR, Parsons TR (1983) Review of the biological oceanography of the Straits of Georgia. Can J Fish Aquat Sci 40:1064-1094

Hollowed AB, Hare SR, Wooster WS (2001) Pacific basin climate variability and patterns of NE Pacific marine fish production. Prog Oceanogr 49:257-282

Hudson RJM, Morel FMM (1993) Trace metal transport by marine microorganisms: implications of metal coordination kinetics. Deep-Sea Res I 40:129-150

Hutchins DA, Bruland KW (1998) Iron-limited diatom growth and Si:N uptake ratios in a coastal upwelling regime. Nature 393:561-564

Hutchins DA, DiTullio GR, Zhang Y, Bruland KW (1998) An iron limitation mosaic in the California upwellng regime. Limnol Oceanogr 43:1037-1054

Johnson WR, Royer TC, Luick JL (1988) On the seasonal variability of the Alaska coastal current. J Geophys Res 93: 12423-12437

Ladd C, Stabeno P, Cokelet ED (2005) A note on cross-shelf exchange in the northern Gulf of Alaska. Deep-Sea Res II 52:667-679

Landry MR (1993) Estimating rates of growth and grazing mortality of phytoplankton by the dilution method. In: Kemp PF, Sherr BF, Sherr EB, Cole JJ (eds) Handbook of methods in aquatic microbial ecology. Lewis Publishers, Boca Raton, FL, p 715-722

Landry MR, Hassett RP (1982) Estimating the grazing impact of marine micro-zooplankton. Mar Biol 67:283-288

Macdonald RW, McLaughlin FA, Wong CS (1986) The storage of reactive silicate samples by freezing. Limnol Oceanogr 31:1139-1142

Martin JH, Gordon RM, Fitzwater S, Broenkow WW (1989) VERTEX: phytoplankton/iron studies in the Gulf of Alaska. Deep-Sea Res 36:649-680

Miller CB, Frost BW, Wheeler PA, Landry MR, Welschmeyer N, Powell TM (1991) Ecological dynamics in the subarctic Pacific, a possibly iron-limited ecosystem. Limnol Oceanogr 36:1600-1615

Mysak LA (1986) El Niño, interannual variability and fisheries in the NE Pacific Ocean. Can J Fish Aquat Sci 43:464-497

Napp JM, Incze LS, Ortner PB, Siefert DLW, Britt L (1996) The plankton of Shelikof Strait, Alaska: standing stock, production, mesoscale variability and their relevance to larval fish survival. Fish Oceanogr 5 (Suppl 1):19-38

OCSEAP (Outer Continental Shelf Environmental Assessment Program) (1986) Marine fisheries: resources and environments. In: Hood DW, Zimmerman ST (eds) The Gulf of Alaska: physical environment and biological resources. US Department of Commerce, Washington, DC, p 417-458

Peterson WT, Schwing FB (2003) A new climate regime in NE Pacific ecosystems. Geophys Res Lett 30:1896, doi: 10.1029/2003GL017528

Reed RK, Schumacher JD (1986) Physical oceanography. In: Hood DW, Zimmerman ST (eds) The Gulf of Alaska: physical environment and biological resources. US Department of Commerce, Washington, DC, p 57-75

Royer TC (1981) Baroclinic transport in the Gulf of Alaska. Part II. A fresh water driven coastal current. J Mar Res 39: 251-266

Sambrotto RN, Lorenzen CJ (1986) Phytoplankton and primary production. In: Hood DW, Zimmerman ST (eds) The Gulf of Alaska: physical environment and biological resources. US Department of Commerce, Washington, DC, p 249-282 
Smayda TJ (1997) Harmful algal blooms: their ecophysiology and general relevance to phytoplankton blooms in the sea. Limnol Oceanogr 42:1137-1153

Stabeno PJ, Reed RK, Schumacher JD (1995) The Alaska coastal current: continuity of transport and forcing. J Geophys Res 100:2477-2485

Stabeno PJ, Bond NA, Hermann AJ, Kachel NB, Mordy CW, Overland JE (2004) Meteorology and oceanography of the Northern Gulf of Alaska. Cont Shelf Res 24:859-897

Strom SL, Brainard MA, Holmes J, Olson MB (2001) Phytoplankton blooms are strongly impacted by microzooplankton grazing in coastal North Pacific waters. Mar Biol 138:355-368

Editorial responsibility: Otto Kinne (Editor-in-Chief), Oldendorf/Luhe, Germany
Strom SL, Macri EL, Olson MB (in press) Microzooplankton grazing in the coastal Gulf of Alaska: variations in topdown control of phytoplankton. Limnol Oceanogr

Weingartner TJ, Danielson SL, Royer TC (2005) Freshwater variability and predictability in the Alaska Coastal Current. Deep-Sea Res II 52:169-191

Whitney FA, Crawford WR, Harrison PJ (2005) Physical processes that enhance nutrient transport and primary productivity in the coastal and open ocean of the subarctic NE Pacific. Deep-Sea Res II 52:681-706

Wilson JG, Overland JE (1986) Meteorology. In: Hood DW, Zimmerman ST (eds) The Gulf of Alaska, physical environment and biological resources. US Department of Commerce, Washington, DC, p 31-54

Submitted: July 6, 2005; Accepted: April 7, 2006

Proofs received from author(s): November 27, 2006 